\title{
Enhancing Mortgage Credit Availability Among Underserved ANd Higher Credit-Risk Populations: An Assessment of Default and Prepayment OPTION EXERCISE AMONG FHA-INSURED BORROWERS
}

\author{
by \\ Yongheng Deng and Stuart Gabriel \\ Lusk Center for Real Estate \\ School of Policy, Planning and Development and Marshall School of Business \\ University of Southern California \\ 331 Lewis Hall \\ Los Angeles, California 90089-0626 \\ ydeng@usc.edu and sgabriel@marshall.usc.edu
}

August, 2002

Recipient of the Best Paper Award at the Joint International Meetings of the American Real Estate and Urban Economics Association and the Asian Real Estate Society, Seoul, Korea, July 2002. This project was funded by the U.S. Department of Housing and Urban Development under Contract: C-OPC 18484 Task Order 6. The authors gratefully acknowledge Dr. Robert Cotterman at Unicon Research Corporation for data preparation and Lihong Yang for excellent research assistance. The authors received helpful comments from participants of the 2002 Cambridge-Maastricht Real Estate Symposium and from Dr. Harold Bunce at the U.S. Department of Housing and Urban Development. Any opinions expressed or implied are those of the authors and do not necessarily reflect the views or policies of the U.S. Department of Housing and Urban Development or the U.S. Government. 


\title{
Enhancing Mortgage Credit Availability Among Underserved ANd Higher Credit-Risk Populations: An Assessment of Default and Prepayment OPTION EXERCISE AMONG FHA-INSURED BORROWERS
}

\begin{abstract}
While prior analyses have provided substantial evidence of elevated default probabilities among mortgages originated to lower income, less credit worthy and minority borrowers, those risks may be offset by the reduced prepayment probabilities of those loans. To the investor in FHA-insured mortgages, such offsets could serve to appreciably reduce total loan termination risk and in so doing boost investment returns. To assess those effects, this paper employs micro-data from the FHA to estimate an option-based hazard model of the competing risks of mortgage termination. The empirical model derives from option theory and includes controls for mortgage put and call options, borrower credit worthiness, and a large number of other contemporaneous and time-invariant indicators of borrower, loan, and locational risk.

Results of the analysis indicate that the elevated default probabilities of loans originated to lower credit quality and minority borrowers are more than offset by their reduced prepayment risks. The estimated cumulative probability of mortgage termination among lower credit-quality and African-American borrowers is only about three-fourths that of higher credit-quality and white borrowers, respectively. Recognition of this mortgage performance advantage should enhance the willingness of lenders and investors to originate and acquire such loans and at more competitive pricing. Findings suggest that the extension of mortgage credit to less credit-worthy and underserved borrowers, in a manner consistent with their lower termination risks, would serve to advance both their homeownership opportunities and related federal housing policy objectives.
\end{abstract}

(JEL G21, J78, R20) 
Recent years have witnessed ongoing research and policy debate as regards the extension of mortgage credit to underserved, minority, and higher credit-risk populations. In part, analyses have derived from articulated polices of both the Clinton and Bush Administrations, which have sought to advance the homeownership opportunities of underserved and minority groups. Research accordingly has sought to identify the determinants of persistent disparities in both mortgage origination and homeownership attainment among targeted and non-targeted groups, (see, for example, Painter, Gabriel and Myers [2001], Coulson [1999], Deng, Quigley and Van Order[1996], Rosenthal [2001]). On the mortgage side, studies largely have focused on the role of borrower credit risk and credit constraint in the analysis of mortgage loan origination and performance (see, for example, Ambrose and Capone [1998, 2000], Ondrich, Ross and Yinger [2000], Berkovec, Canner, Gabriel, and Hannon [1998], Avery et al [1996], Goering and Wienk [1996], Munnell et al [1996], Canner, Passmore and Smith [1994], Gabriel and Rosenthal [1991]).

While prior studies have provided substantial evidence of elevated default risk among lowerincome, minority, and less credit-worthy mortgage borrowers, there exists little evidence as to any offset of those risks via the slower prepayment speeds of underserved borrower groups. To mortgage lenders and investors, such an offset could serve to appreciably reduce total loan termination probabilities so as to boost investment returns. Indeed, analyses of loan termination probabilities should account for the joint and competing nature of borrower prepayment and default option exercise (see, for example, Deng, Quigley, and Van Order [2000]).

Recent studies of the micro-foundations of mortgage loan performance suffer from numerous limitations, however, in the assessment of prepayment and default risks. Most prior analyses fail to include contemporaneous valuation of the mortgage put and call options over the life of the mortgage; further, many analyses have focused on prediction of mortgage default without consideration of prepayment risk and vice-versa (see, for example, Berkovec et al [1998], Avery et al [1996], Gabriel and Rosenthal [1991], and Pennington-Cross and Nichols [2000]). Recent 
papers (see, for example, Cotterman [2001], Deng, Quigley and Van Order [1996, 2000], Deng and Quigley [2001], Archer, Ling and McGill [2001], and Van Order and Zorn [2001]) often fail to include important information on borrower creditworthiness (credit scores) and are further circumscribed by the limited availability of other borrower, loan, and locational information important to prediction of loan performance, including indicators of borrower wealth, mortgage payment-to-income and debt-to-income ratios, and other common underwriting controls.

This study applies a competing risk framework to model the micro-foundations of FHAinsured mortgage performance. The FHA data are well suited to analyses of loan default, given the inclusion in the program of large numbers of relatively higher credit risk borrowers. The data further enable an assessment of whether those same higher credit risk and underserved borrowers prepay their mortgages more slowly, due perhaps to problems of access to mortgage finance, difficulties in mortgage qualification, limited borrower knowledge of mortgage refinance opportunities, or reduced residential mobility. To the extent the prepayment risk of mortgages originated among lower-income, lower credit-quality, and minority borrowers is relatively damped, it should be reflected in the pricing of those loans. Indeed, from a mortgage pricing perspective, the reduced prepayment risk associated with those FHA-insured borrower groups may serve to mitigate their higher default probabilities.

The analysis employs an option-based hazard model to simultaneously assess the competing risks of FHA-insured mortgage default and prepayment. The empirical model derives from option theory and employs well-specified contemporaneous proxies for the mortgage put and call options in the default and prepayment equations. Given the availability of high quality micro data, the estimating equations control for borrower credit worthiness (credit scores) and other common underwriting variables among the approximately 30 contemporaneous and timeinvariant indicators of borrower, loan, and locational risk.

Results of the analysis strongly support the predictions of option theory in explaining the exercise of default and prepayment options among FHA-insured mortgage borrowers. The 
estimates confirm that the intrinsic values of the call and put option variables are positive and highly significant in the exercise of the prepayment and default options; respectively. Results further suggest that a higher value of the put option (probability of negative equity) reduces the risk of mortgage prepayment.

Research findings further point to the importance of other borrower, loan, and market characteristics in the estimation of mortgage termination risks. As would be expected, higher credit score borrowers are less likely to exercise the default option, whereas lower credit score borrowers are less likely to prepay. In that regard, the 5-year cumulative probability of prepayment is about 10 percentage points higher among borrowers with scores in excess of 680 than among those with scores below 620. The 5-year cumulative prepayment probabilities of Black and Hispanic borrowers are about 14 and 7 percentage points lower than those of white borrowers, respectively.

Overall, results indicate the appropriateness of the competing risk specification and illustrate the importance of slower prepayment speeds among higher credit risk and underserved borrowers. As is evidenced below, the substantially elevated default probabilities of higher credit risk FHA borrowers are more than offset by their damped prepayment propensities, resulting in significantly lower loan termination probabilities overall. Indeed, the estimated cumulative probability of mortgage termination at five years post-origination among high default risk FHA borrowers (42 percent) is only 3/4ths that of low-default risk FHA borrowers (55 percent). Lender and investor recognition of this mortgage performance advantage should facilitate their greater willingness to originate and acquire higher credit-risk FHA-insured loans and at more competitive prices. Research findings suggest that the extension of mortgage credit to less creditworthy and underserved borrowers, in a manner consistent with their lower termination risks, would serve to advance both their homeownership attainment and related federal housing policy objectives. 
The plan of the paper is as follows. Section I presents the basic model and estimation strategy. Section II describes the FHA database whereas section III discusses estimation and simulation results. Conclusions and implications for mortgage pricing are discussed in section IV.

\section{Methodology}

Recent research on mortgage markets indicates that borrower exercise of mortgage prepayment and default options are behaviorally distinct, but not independent. For example, one cannot calculate accurately the economic value of the default option without considering simultaneously the financial incentive for prepayment (Deng, Quigley, and Van Order [2000]). Furthermore, risk preferences and other idiosyncratic differences may vary widely across borrowers. Appropriate modeling of prepayment and default risks is then crucial to the pricing of mortgages and to an understanding of the economic behavior of homeowners.

This analysis applies a proportional hazard framework to assess the competing risks of mortgage termination by prepayment and default. The model derives from option theory and predicts that well-informed mortgage borrowers in a perfectly competitive market will exercise the default or prepayment option in order to increase their wealth. Theory suggests that mortgage borrowers will exercise the default option when the market value of the mortgage equals or exceeds the market value of the collateral. Similarly, borrowers can increase their wealth by refinancing their loans when the market value of the mortgage exceeds the par value of the mortgage. However, these two options compete against each other. For example, when an individual decides to exercise the default option, she is making the decision to forego future exercise of the prepayment option. Kau et al $(1992,1995)$ have outlined the theoretical relationships among the options, and Schwartz and Torous (1993) have demonstrated their practical importance. Furthermore, empirical evidence shows that certain borrower characteristics that have strong association with one option may have the opposite association with the other option. For example, a lower-income borrower with a poor credit history may have 
higher default risks but lower refinance risks, due to those same credit problems and/or liquidity constraints that typically affect the ability to qualify for a new loan.

This paper follows Deng, Quigley, and Van Order (2000) in application of an option-based hazard model to simultaneously estimate the competing risks of mortgage loan default and prepayment. In this model, $T_{p}$ and $T_{d}$ are discrete random variables representing the duration of a mortgage prior to termination by the mortgage holder in the form of prepayment or default, respectively. Following the Cox model, the joint survivor function conditional on $\xi_{p}, \xi_{d}, r, H, Y$, and $X$ can be expressed in the following form: ${ }^{1}$

$$
\begin{aligned}
& S\left(t_{p}, t_{d} \mid r, H, Y, X, \xi_{p}, \xi_{d}, \theta\right) \\
&=\exp \left\{-\xi_{p} \sum_{k=1}^{t_{p}} \exp \left(\gamma_{p k}+\beta_{p_{1}}^{\prime} g_{p k}(r, H, Y)+\beta_{p_{2}}^{\prime} X\right)\right. \\
&\left.\quad-\xi_{d} \sum_{k=1}^{t_{d}} \exp \left(\gamma_{d k}+\beta_{d_{1}}^{\prime} g_{d k}(r, H, Y)+\beta_{d_{2}}^{\prime} X\right)\right\} .
\end{aligned}
$$

In this formulation $g_{j k}(r, H, Y)$ are time-varying variables measuring the financial values of the prepayment and default options $(j=p, d)$. The equation includes empirical measures of the intrinsic values of prepayment option (the call option) as well as the default option (the put option). The relevant interest rates and property values are $r$ and $H$, respectively, whereas $Y$ is a vector of other variables that also are relevant to an empirical description of the market values of the default and prepayment options.

Following Deng, Quigley and Van Order (2000), the "Call Option" for each individual FHA loan borrower is defined as:

$$
\text { Call_Option }{ }_{i, k}=\frac{V_{i, m}-V_{i, r}^{*}}{V_{i, m}}
$$

where

\footnotetext{
${ }^{1}$ The proportional hazard model introduced by Cox (1972) provides a framework for considering the contingent claims model empirically and for measuring the effect of financial options on the behavior of mortgage holders.
} 


$$
\begin{aligned}
V_{i, r}^{*} & =\sum_{S=1}^{T M_{i}-k_{i}} \frac{P_{i}}{\left(1+r_{i}\right)^{S}}, \\
V_{i, m} & =\sum_{S=1}^{T M_{i}-k_{i}} \frac{P_{i}}{\left(1+m_{\tau_{i}+k_{i}}\right)^{S}},
\end{aligned}
$$

$r_{i}$ is mortgage note rate, $T M_{i}$ is the mortgage term, $k_{i}$ is the mortgage duration after origination at time $\tau_{i}, m_{\tau_{i}+k_{i}}$ is the market interest rate, and $P_{i}$ is the monthly mortgage payment.

Typically, we cannot measure directly from the micro data the extent to which the default option is "in the money" without knowing the entire path of individual house values. We can, however, estimate the probability of exercise of the "put option" based on the initial loan-to-value ratio and the diffusion process of house prices. Specifically, the "put option" variable is defined as:

$$
P u t_{-} \text {Option }_{i, k}=\Phi\left(\frac{\left(\log V_{i, m}-\log M_{i, k}\right)}{\sqrt{\omega}}\right),
$$

where $\Phi(\cdot)$ is cumulative standard normal distribution function, $\omega$ is an estimated variance, $V_{i, m}$ is defined previously, and the market value $M_{i}$ of property $i$, purchased at a price of $C_{i}$ at time $\tau_{i}$ and evaluated $k_{i}$ quarters thereafter is

$$
M_{i, k}=C_{i}\left(\frac{I_{j, \tau_{i}+k_{i}}}{I_{j, \tau_{i}}}\right),
$$

where the term in parentheses follows a log normal distribution and $I_{j, \tau_{i}}$ is an index of house prices in metropolitan area $j$ at time $\tau_{i}$.

The vector $X$ is comprised of other non-option-related variables, including both time-varying and time-invariant determinants of mortgage performance. Time-varying controls include the unemployment rate of the MSA, the log value of a Herfindahl-Hirschmann Index of metropolitan mortgage lending market concentration, interactions of put and call options with borrower credit scores, and interactions of black and Hispanic households with the log value of the Herfindahl- 
Hirschmann Index. ${ }^{2}$ Time-invariant variables include categorical measures of borrower credit score, borrower race/ethnicity, borrower housing expenditure-to-income ratio, borrower debt-toincome ratio, borrower gender and marital status, borrower age group, first-time homebuyer status, seller offer to buy down the mortgage rate, whether the mortgage is amortized in 30 years or less, whether the property is located in the central city, whether the property is located in a rural area, and whether the property is a new home. Other continuous controls include mortgage loan-to-value ratio at origination, log value of property appraisal value, number of dependents in borrower's household, log value of borrower liquid assets, and log value of household income. Also included among controls for mortgage performance are census tract level variables reflecting neighborhood racial/ethnic mix, proportion rental occupied stock, and ratio of census tract to MSA median income.

Unobserved error terms associated with the hazard functions for prepayment and default are denoted $\xi_{p}$ and $\xi_{d}$, respectively. $\theta$ is a vector of parameters (e.g., $\gamma$ and $\beta$ ) of the hazard function. $\gamma_{j k}$ are parameters of the baseline hazard function. The baseline may be estimated with a flexible form suggested by Han and Hausman (1990), such that:

$$
\gamma_{j k}=\log \left[\int_{k-1}^{k} h_{0 j}(s) d s\right], \quad j=p, d .
$$

Alternatively, the form of the baseline may be imposed by employing mortgage industry performance benchmarks such as those reflected in the "PSA and SDA curves." 3

\footnotetext{
${ }^{2}$ The measure of market concentration employed in the analysis is the Herfindahl-Hirschmann Index, defined as the sum of the squared market shares of all providers of home purchase loans in the market, where a market is defined as a metropolitan statistical area. This measure of market concentration was used successfully by Berkovec, Canner, Gabriel, and Hannan (1998) to explain differences in competitive conditions across MSAs.

${ }^{3}$ The Public Securities Association (PSA) has defined a prepayment measurement standard that has been widely adopted by fixed-income securities analysts. This is a series of 360 monthly prepayment rates expressed as constant annual rates. The series begins at 0.2 percent in the first month and increases by 0.2 percent in each successive month until month 30 , when the series levels out at 6 percent per year until maturity. (See Hayre [2001] pp. 24-25 for details.) The Bond Market Association has also developed a Standard Default Assumption (SDA) that is widely used as a benchmark to measure loan default experience. The SDA series begins at 0.02 percent annual constant rate in the first month and increases by 0.02 percent in each successive month until month 30, when the series levels out at 0.6 percent per year for the next 30 months. Then the series declines by 0.0095 percent each month from month 61 to month 120 . At that point, the default rate remains level through maturity. (See Hayre [2001] pp. 168-169 for details.) Prepayments and defaults are often reported as simple linear multiples of the PSA and SDA schedules, respectively. When the PSA and SDA schedules are utilized as baselines for the prepayment and default functions, respectively, the factors of proportionality estimated from the hazard model can be expressed simply as a percentage of the PSA and SDA experiences.
} 
The estimated competing risks of prepayment and default are then used to simulate the potential risks to FHA mortgage lending as derived from various borrower and loan characteristics, notably including loan-to-value and payment-to-income ratios as well as borrower liquid assets and credit scores. Further simulations are undertaken for hypothetically comprised high- and low-credit risk borrower groups. As indicated below, total loan terminations from default and prepayment among higher credit risk borrowers are estimated to be substantially less than those of low credit risk borrowers, suggesting enhanced investor profitability of those loans when such prepayment option is "in the money".

\section{Data}

The principal data utilized in this study consist of a large random sample of FHA-insured home purchase loans originated during the 1992-1996 period. ${ }^{4}$ All loans are fully amortizing, most with thirty-year terms. The individual loan records contain information on a large number of loan, borrower, and property-related characteristics and also indicate termination date of each loan and reason for termination. ${ }^{5}$ Attached to the loan record files are borrower credit scores at time of loan application as well as measures of local housing market performance including house price appreciation and volatility. ${ }^{6}$ Further, using a census tract indicator for each property location, each loan record file is matched to neighborhood socioeconomic and housing market indicators from the 1990 Census of Population and Housing. Other neighborhood or metropolitan area level variables, including unemployment rates, also are appended to the record file. FHA data on the race of the borrower and census measures of neighborhood racial composition enable

\footnotetext{
${ }^{4}$ The final sample consists of 12,012 loans randomly selected from the 120,342 endorsed loans applications from 1992, 1994, and 1996. Loan origination dates are concentrated in those three calendar years but also spread out into other years. The 120,342 loan database provided by Unicon Research is a choice-based sample with weights that account for choice-based sampling and differential loan losses by race and loan status. For each of the application years, the weighted cumulative default rates for the loans comprising the sub-sample of 12,012 loans were found to be quite similar to those observed in the parent population. The individual loan files are observed on a monthly basis from month of origination through that of termination, maturation, or through the end of 2000 for active loans.

${ }^{5}$ As defined for this analysis, default outcomes include both lender foreclosure and situations where the borrower conveys title of the property in lieu of foreclosure. Loan prepayment is defined as pay-off prior to completion of the amortization period.

${ }^{6}$ Borrower credit score information is provided by Equifax and Trans Union. If the data provides both Equifax and Trans Union scores for an individual borrower, we take the average of the two scores. Numerous recent papers (see, for example, Avery et al [1996]) point to the importance of controls for borrower credit score in micro-analyses of mortgage default likelihoods.
} 
assessment of race-related effects associated with the performance of FHA-insured loans. The FHA data set encompasses nearly 300 different metropolitan areas, allowing for substantial variability in the structure of local lending markets.

The FHA-insured data are well-suited to analyses of loan performance, given the inclusion in the program of large numbers of relatively high credit-risk borrowers. Although both FHA and conventional mortgage applications are evaluated according to formal underwriting criteria, the FHA guidelines are less strict than those of conventional lenders, particularly as regards downpayment requirements and the acceptable ratios of housing expense-to-income and total debt expense-to-income. Approximately 61 percent of the loans in the sample have loan-to-value ratios exceeding 95\%. Similarly, the debt obligation ratios of the FHA borrowers in the sample are relatively high, averaging about $35 \%$ for the ratio of total debt payments-to-income and about $23 \%$ for the ratio of housing debt payments-to-income. First-time homebuyers and moderateincome borrowers comprise a large portion of the sample, and minorities are well represented as well.

Table 1 displays the means and variances of the time-invariant covariates, whereas Table 2 provides the same for time-varying covariates at origination and termination. As is evidenced in Table 1, some two-thirds of FHA borrowers were first-time buyers; the average mortgage loan-tovalue ratio among sampled loans was 94 percent. As would be expected, the majority of sampled loans were to married borrowers, aged 25-35, with housing expense-to-income ratios of 20-38\%, debt-to-income ratios of $20-41 \%$, and credit scores in the range of $620-740$. As would be expected (Table 2), among prepaid loans, the computed mean of the call option value at termination substantially exceeded that at time of loan origination. Owing to equity build-up over the loan period, the value of the put option at the time of loan origination (probability of negative equity) substantially exceeded that at time of loan termination. 


\section{Empirical Results}

Our competing risks analysis is based on a stratified sample of FHA loan data provided by HUD. A weighting variable is used in the maximum likelihood estimation (MLE) procedure to correct the possible sample selection bias. The weight addresses the choice-based sampling of mortgage files across race and loan status cells. More specifically, the weight is defined as the inverse of probability that the loan observation is being selected from a cell where it was sampled. ${ }^{7}$ The competing risks of default and prepayment are estimated jointly.

Table 3 presents three variants of the competing risks model of FHA loan termination. Each model contains separate flexible baseline functions for default and prepayment that follow Han and Hausman (1990). ${ }^{8}$ Model 1 does not control directly for the values of the call and put options in the estimating equations. Further, that model excludes controls for mortgage borrower credit scores. Accordingly, the specification of Model 1 approximates that of most prior micro-data analyses of FHA mortgage default and provides a benchmark for the competing risks specifications discussed below. However, in contrast to most prior analyses, which were restricted to controls for local market conditions at the time of loan origination, Model 1 includes several time-varying proxies. ${ }^{9}$ The time-varying covariates include SMSA level unemployment rates, log value of a Herfindahl-Hirschmann index of mortgage market concentration, and an interaction of black and Hispanic households and the Herfindahl Index terms. Model 2 extends Model 1 by including the contemporaneous values of both the call and put options in both risk equations. Model 3 extends Model 2 by including the borrower's credit score information. In addition, the put and call values are interacted with borrower credit scores. All specifications also include a rich set of time-constant controls for borrower, loan, and locational determinants of exercise of the default and prepayment options. Overall, the competing risks models are well-

\footnotetext{
${ }^{7}$ Here we assume that the sampling mechanism is independent of error distribution of the competing risks of FHA loan prepayment and default risks.

${ }^{8}$ We also estimate these models using 100\% SDA and PSA curves as our baselines for loan default and prepayment, respectively. The estimated parameters are robust to alternative specifications of baseline hazards functions.

${ }^{9}$ For a recent micro-data based analysis of the FHA default experience, see Cotterman (2001).
} 
specified and control for approximately 30 different characteristics of the loan, the borrower, and the census tract or area in which the property is located.

As evidenced in Model 1, estimation results indicate that increases in local unemployment rates negatively affect the exercise of the prepayment option but positively affect exercise of the default option. These results are highly significant across model specifications and are consistent with previous studies based on agency conforming loan data (see for example Deng, Quigley, and Van Order [2000]).

The estimates from Model 1 suggest that the initial loan-to-value ratio is negatively associated with prepayment risk and positively associated with default risk..$^{10,11}$ The estimated LTV coefficients are statistically significant across all model specifications. Higher levels of LTV may reflect in part borrower difficulties in loan re-qualification that diminish the exercise of the prepayment option. Model 1 also reports that prepayment likelihoods vary positively with mortgage expense burdens. An increase in the ratio of housing expense-to-income from below $20 \%$ to $20-38 \%$ and to in excess of $38 \%$ results in statistically significant increases in the likelihood of mortgage prepayment. However, results of the competing risk specifications (models 2 and 3) suggest that borrowers with housing expense-to-income ratios in the 20-38\% range are most likely to prepay, whereas those with ratios below $20 \%$ or in excess of $38 \%$ are less likely to prepay. In contrast, borrower total debt-to-income burdens do not figure significantly in the exercise of prepayment options. In the competing risk model, neither the front- or back-end mortgage obligation ratio is significant in the exercise of the default option. ${ }^{12,13}$

\footnotetext{
${ }^{10}$ In many prior studies, the ratio of the size of loan to the market value of the property at the time of loan origination is particularly important in predicting default probability, with higher LTVs associated with higher likelihoods of default. See, for example, Berkovec, Canner, Gabriel, and Hannon (1998).

${ }^{11}$ Note that the model is estimated using a non-random choice-based sample. With the sample selection weights, we obtain consistent estimates for the regression point estimates. However, since the weights vary by individual, the estimated second moments are upward biased, in turn suggesting that the t-statistics on the regression coefficients are downward biased. Accordingly, those estimated coefficients that appear to be borderline significant may indeed be estimated with a high level of statistical significance.

${ }_{12}$ The two "obligation ratios" of housing expense-to-income and total debt payment-to-income are presented as a series of dummy variables indicating specific ranges of these ratios. This approach was adopted because the cut-off values are relevant to FHA loan underwriting guidelines. Therefore we allow for these nonlinearities in our estimation procedure.

${ }^{13}$ Earlier micro-data analyses of default likelihood indicate the importance of increases in the front-end ratio to exercise of the default option. As suggested, those results are not robust to the competing risk specification of mortgage default and
} 
Model 1 indicates that prepayment likelihoods are elevated among loans subject to interest rate "buy-downs". The estimated coefficient associated with that variable is insignificant in the default equation. In contrast, exercise of the prepayment option is significantly damped among first-time borrowers and single-female borrowers. Compared to married couples, single male borrowers are of significantly higher default risk. As would be expected, shorter-term mortgage loans are characterized by significantly lower prepayment and default risks. Borrowers with a larger number of dependents are significantly less likely to exercise the prepayment option but significantly more likely to exercise the default option. Borrowers with greater liquid assets (and hence fewer liquidity constraints) are less likely to exercise the default option; however, borrower liquid assets do not significantly affect exercise of the prepayment option. Younger and higher income borrowers are more likely to prepay; however, those factors are not statistically significant in the exercise of the default option. Having accounted for borrower and loan characteristics, findings indicate that census tract level controls are not significant to the exercise of the mortgage options. ${ }^{14}$ Further, estimation findings are largely robust to the exclusion of those controls. Research findings also indicate little systematic variations in loan termination propensities across central city, suburban, or rural areas.

The competing risks model also tests for variation in the exercise of default and prepayment options across borrower race and ethnicity. As evidenced in Model 1, Asian borrowers do not appear to be statistically different from white borrowers in their exercise of either the mortgage put or call options. In marked contrast, both Hispanic and black borrowers are characterized by statistically damped prepayment likelihoods. In this case, the reduced exercise of the prepayment option among Hispanic and black borrowers serves to enhance the profitability of those loans among investors in FHA-insured mortgages. In contrast to earlier studies, results of the estimation of the competing risks model do not indicate the presence of statistically elevated

prepayment.

${ }^{14}$ Estimation of Table 3 inclusive of census tract controls is contained in Appendix A, Table A1. 
default risks among black and Hispanic borrowers. ${ }^{15}$

Our empirical results show damped exercise of the default option in more concentrated metropolitan lending markets (as measured by the Herfindahl-Hirschmann Index). In general, results are consistent with the hypothesis that in highly concentrated lending markets, lenders may impose more stringent underwriting standards so as to improve loan quality and reduce the risk of default. The Herfindahl-Hirschmann Index of mortgage market concentration also is interacted with the minority (black and Hispanic) borrower status variables. For the most part, results fail to suggest differential minority borrower exercise of default and prepayment options in more concentrated lending markets. ${ }^{16}$

Model 2 extends Model 1 through the introduction of the option-related time-varying covariates into both the prepayment and default equations. The call and put option controls are similar to those used by Deng, Quigley, and Van Order (1996). Note, however, that the FHA data utilized herein enables a much richer specification of the competing risks than has been previously estimated using conventional loan data (see, for example, Deng, Quigley and Van Order [1996, 2000], and Van Order and Zorn [2001]). The estimates confirm that the call option value is positive and highly significant in the exercise of the prepayment option; similarly, the value of the put option (probability of negative equity) also is positive and highly significant in the exercise of the default option. In other words, declines in mortgage interest rates that bring the call option "into-the-money" will lead to a high volume of prepayment activities, as is observed in the data in the sharp upward movement in mortgage prepayment activity in both 1993 and 1998. On the other hand, when the probability of negative equity becomes imminent, the incidence of default increases dramatically. These findings strongly support the predictions of

\footnotetext{
${ }^{15}$ This result stands in marked contrast to earlier results indicating statistically elevated default probabilities among black borrowers (see, for example, Berkovec, Canner, Gabriel, and Hannon [1998]). As well appreciated, however, the FHA data utilized herein derives from a more recent period. Further, earlier results did not derive from a competing risks model of mortgage default and prepayment replete with credit score information and other time-varying controls.

${ }^{16}$ Among black and Hispanic borrowers, lending market concentration is statistically insignificant in determination of default likelihood. Results similarly failed to indicate a statistically different prepayment risk between blacks and whites in a more concentrated lending market.
} 
option theory in explaining the exercise of default and prepayment options on the part of mortgage borrowers.

Model 2 further suggests that a higher probability of negative equity significantly reduces the risk of mortgage prepayment. Such an outcome is indeed plausible, in that households with poor equity positions may be less willing to exercise the refinance option owing to equity values that may be insufficient to refinance the remaining loan balance. On the other hand, the value of the call option exerts a significant positive influence on default propensities. This may be explained by the fact that when market rates drop, the value of call option increases, as does the market value of the mortgage. Relative to the market value of the outstanding balance of the loan, the underlying collateral (the house) is less valuable to the borrower so as to encourage borrower exercise of the default option. These findings are consistent with Deng, Quigley, and Van Order (2000). For the most part, the remaining estimated coefficients of Model 2 are robust to the inclusion of the call and put option values.

Model 3 extends Model 2 through the introduction of borrower credit scores into both the default and prepayment equations. The credit scores are entered in a nonlinear fashion roughly consistent with loan underwriting policy. As evidenced in Model 3, the credit score terms are statistically significant in the default equation. As would be expected, relative to the excluded highly credit qualified borrowers (credit score $>740$ ), lower score borrowers are more likely to exercise the default option. On average, the default propensity of the middle qualified group (credit score in the 620-680 range) is almost twice as high as the more highly qualified group (score in the 680-740 range), whereas the default risks associated with the least qualified group (credit score below 620) are about 2.3 times higher than the group with score between $680-740 .{ }^{18}$

\footnotetext{
${ }^{18}$ The default likelihood of the middle qualified group (credit score in the 620-680 range) relative to that of the more highly qualified group (score in the $680-740$ range) is $1.366 / 0.799=1.9$, whereas the default risks associated with the least qualified group (credit score below 620) relative to the group with a score between 680-740 is $1.684 / 0.729=2.3$.
} 
The credit score variables also are interacted with the time-varying estimates of the call and put options. As evidenced in Model 3 results, the interactive credit score and call option terms are positive and highly significant in the loan prepayment equation. Further, the estimated coefficients indicate more ruthless exercise of the call option among the most credit worthy borrowers. ${ }^{19}$ Among borrowers with credit scores in excess of 740 , for example, the influence of the call option value on prepayment propensities is about one-third higher than that of borrowers with credit scores below 620. The estimated interactions between credit scores and the call option proxy also underscore the relatively damped prepayment propensities of less credit worthy borrowers, even as that prepayment is "in the money". Similarly, the estimated coefficients on the interactive put option and credit score terms are positive and highly significant, suggesting a U-shaped relation with elevated propensities to default among both relatively low and high credit score borrowers. The estimated coefficients of the interactive put option and credit score variables also are negative and highly significant in the loan prepayment equation.

Table 4 reports on the unadjusted cumulative probability of prepayment and default by various covariates and at the end of post-origination years one, three, and five. The unadjusted probabilities derive from the full sample of FHA loans. Overall, the data indicate very substantial upward movement in prepayment probabilities over the five years subsequent to mortgage origination; default propensities similarly are shown to move up perceptibly over that period. The top panel reports on the cumulative probabilities of prepayment and default by borrower race. The data indicate elevated default probabilities as well as damped prepayment probabilities among black and Latino borrowers relative to white or Asian borrowers. As would be expected, the data also indicate substantially higher prepayment probabilities and similarly damped default probabilities among those borrowers with liquid assets in excess of median levels. Among other borrower and loan characteristics, elevated prepayment propensities are observed among loans with LTVs below 95 percent and housing expense-to-income ratios of 20-38 percent, and among

\footnotetext{
${ }^{19}$ These findings are consistent with Bennett et al (2001).
} 
repeat buyers. Those same borrower and loan categories are associated with relatively damped five-year cumulative default probabilities.

Table 5 simulates the cumulative probabilities of prepayment and default by those borrower and loan characteristics identified in Table 4. As in Table 4, those probabilities are computed for one, three, and five years post loan origination. The simulations are based on a ten percent random sample of loans originated in June 1992. The baseline borrower is assumed to be a white household purchasing an existing suburban home with a 30-year fixed rate mortgage. The values of the other time-invariant control variables are set at their sample means, whereas time-varying covariates are set at their sample mean in each period. ${ }^{20}$ Those covariates that are the focus of model simulation are specified in the table.

As would be expected, the 5-year cumulative probability of prepayment rises substantially with borrower credit worthiness (as reflected in borrower credit scores). That probability is 23 percent higher among borrowers with scores in excess of 680 than among those with scores below $620([45.67 \%-35.22 \%] / 45.67 \%=23 \%)$. Among white borrowers, for example, the 5-year cumulative probability of prepayment of $43.22 \%$ is about $1-1 / 2$ times the $29.64 \%$ rate estimated for similarly credit worthy blacks. Indeed, computation of cumulative prepayment rates by race and credit worthiness illustrates the strikingly lower prepayment propensities of black borrowers, relative to their white, Latino, and Asian counterparts. Likewise, cumulative default rates among black borrowers are estimated to be substantially in excess of those for other racial groups. At $5.3 \%$, the 5 -year cumulative default rate of highly credit worthy black borrowers is 36 percent higher $([5.30 \%-3.38 \%] / 5.30 \%=36 \%)$ than that of similarly qualified white borrowers.

We also simulated the cumulative probability of prepayment and default by initial loan-tovalue ratios. As would be expected, higher levels of credit risk serve both to elevate default likelihoods and to damp prepayment propensities. For example, as shown in Table 5, at 5 years

\footnotetext{
${ }^{20}$ Among time-invariant controls, for example, the simulation assumes two dependents per household. Further, the average loan-to-value ratio is set equal to 94 percent, whereas the log values of property value, household liquid assets, and family
} 
post loan origination, borrowers with high LTVs (LTVs $\geq 95 \%$ ) are characterized by 1.5 times the default risk $(3.86 / 2.99=1.3)$ of borrowers with lower LTVs. Also evident, however, are the substantially lower prepayment propensities of those high LTV borrowers; at 5 years post loan origination, the prepayment likelihoods of high LTV borrowers were 20 percent below those of lower LTV loans. A similar outcome is evidenced, for example, in the simulation of default and prepayment propensities among more or less credit worthy borrowers. At 5 years post loan origination, borrowers with lower credit scores (credit scores < 620) are characterized by 3-3/4 times the default risk $(8.44 / 2.24=3.77)$ of borrowers with higher credit scores. Those same lower credit score borrowers are characterized by damped prepayment risk relative to their higher credit score counterparts. ${ }^{21}$

The bottom rows of Table 5 provide simulations of default and prepayment propensities among more fully specified high- and low- credit risk borrowers. The precise specification of those borrower profiles is articulated in notes to Table 5. In general, high credit risk borrowers are those with lower levels of liquid assets, poor credit scores, and more aggressively underwritten mortgages (as regards loan-to-value and payments-to-income ratios). With some limited nuance, lower credit risk borrowers are the opposite.

As is evidenced in Table 5, loan performance behavior differs markedly over these borrower risk profiles. For example, by end of year 5 post loan origination, the simulated prepayment propensity of the lower credit risk borrower is about 21 percentage points higher than that of the higher credit risk borrower. However, lower credit risk borrowers are characterized by a 5-year cumulative default propensity that is about 8 percentage points lower than that of their higher

income are set to $11.13,8.54$, and 8.00 , respectively. These simulations further assume that the borrowers are married, firsttime buyers and that the loan interest rate is not subject to buy-down.

${ }^{21}$ Other simulations suggest that by the end of year five post-origination, younger borrowers (age of household head is less than 25 years old) are characterized by 1.4 times the prepayment risks $(46.98 \% / 33.66 \%=1.4)$ of older households (age of household head greater than 45 years old). While the simulated risks of loan default similarly move up over the five-year period post origination, the differences between age groups is slight. Findings further suggest that the cumulative 5-year risk of prepayment is relatively higher among married couples $(41 \%)$ than single females $(38 \%)$. In marked contrast, the 5-year cumulative probability of default among single males is about 1.4 times $(4.71 \% / 3.45 \%=1.4)$ that of single females. We further find little quantitative variation in the cumulative probabilities of default across first-time buyer status. Results of these analyses are available from the authors upon request. 
credit risk counterparts. On net, results provide clear evidence of elevated total loan termination probabilities among the lower credit risk group.

The right-hand columns of Table 5 provide an assessment of total termination risks of FHAinsured mortgage loans. Those risks are defined as the sum of the default and prepayment propensities at the end of years 1,3, and 5. Total loan terminations (from all sources) are relevant to the profitability of investment in FHA-insured mortgages. Typically, those loans not only are FHA-insured, but if pooled and sold also often are backed by a Ginnie Mae guarantee of timely repayment of principal and interest in the event of borrower default. Accordingly, from the perspective of the FHA-backed and Ginnie Mae insured loan investor, a loan termination via default is equivalent to that which derives from prepayment. Clearly, borrower groups with lower total loan termination risks represent more profitable loan investment opportunities, relative to those groups with higher total termination propensities.

As is evident in Table 5, total loan termination risk is substantially elevated among lower credit risk borrowers. In that regard, total termination risk among low credit risk borrowers is about 32 percent $([54.72 \%-41.53 \%] / 41.53 \%=32 \%)$ in excess of that of high credit risk borrowers. As is further apparent, the substantially elevated default probabilities among the high credit risk group are more than offset by the damped prepayment propensities, resulting in significantly lower loan termination propensities overall. Indeed, among high credit risk borrowers, loan termination probabilities via prepayment at the end of year 5 post origination are about 3.3 times that of loan termination propensities from default, while for low credit risk borrowers, prepayment probabilities at the end of year 5 post origination are about 33 times that of default probabilities. Clearly those loans originated among high credit risk borrowers are relatively more profitable to the investor, given their substantially depressed overall termination propensities. 


\section{Summary and Conclusion}

This paper applies micro-data from the FHA to estimate an option-based hazard model of the competing risks of mortgage default and prepayment. The empirical model derives from option theory and includes proxies for mortgage put and call options, borrower credit worthiness, lending market concentration, and numerous other contemporaneous and time-invariant borrower, loan, and locational controls. The estimated competing risks of prepayment and default are then used to simulate the potential risks to FHA mortgage lending as derive from various borrower characteristics, notably including those pertaining to borrower credit worthiness and race.

Results of the analysis strongly support the predictions of option theory in explaining the exercise of default and prepayment options among FHA mortgage borrowers. The estimates confirm that the call option value is positive and highly significant in the exercise of the prepayment option; similarly, the value of the put option (probability of negative equity) also is positive and highly significant in the exercise of the default option. Results further suggest that a higher probability of negative equity reduces the risk of mortgage prepayment. Such an outcome is indeed plausible, in that households with poor equity positions may be less willing to exercise the refinance option owing to equity values that may be insufficient to refinance the remaining loan balance.

Results further point to the importance of other borrower, loan, and market characteristics in the estimation of mortgage termination risks. For example, findings indicate reduced consumer refinance propensity in more concentrated and less competitive loan markets. Among FHA borrowers, the initial loan-to-value ratio is negatively associated with prepayment propensity and positively associated with default propensity. As would be expected, higher credit score borrowers are less likely to exercise the default option, whereas lower credit score borrowers are less likely to prepay. In that regard, the 5 -year cumulative probability of prepayment is 23 percent higher among borrowers with scores in excess of 680 than among those with scores below 620. Relative to white borrowers, estimates suggest that black and Hispanic borrowers are 
statistically less likely to prepay. Indeed, computation of cumulative prepayment rates by race and credit worthiness illustrates the strikingly lower prepayment propensities of black borrowers, relative to their white, Latino, and Asian counterparts.

Overall, results indicate the appropriateness of the competing risk specification and indicate the importance of slower prepayment speeds among higher risk borrowers. As is evidenced, the substantially elevated default probabilities of higher credit risk borrowers are more than offset by their damped prepayment propensities, resulting in significantly lower loan termination propensities overall. Indeed, among high credit risk borrowers, at 5 years post loan origination, loan termination probabilities via prepayment are about 3.3 times those emanating from loan default, while for low credit risk borrowers, prepayment probabilities at the end of year 5 post origination are about 33 times that of default probabilities. For the investor in FHA-insured mortgage pools, the estimated 5-year cumulative probability of mortgage termination among high default risk and minority borrowers is only about three-fourths that of low-default risk and nonminority borrowers, respectively. Recognition of this mortgage performance advantage should enhance the willingness of lenders and investors to originate and acquire such loans and at more competitive pricing. Findings suggest that the extension of mortgage credit to less credit-worthy and underserved borrowers, in a manner consistent with their lower termination risks, would serve to advance both their homeownership opportunities and related federal housing policy objectives. 


\section{REFERENCES}

Ambrose, Brent W. and Capone, Charles A. "Modeling the Conditional Probability of Foreclosure in the Context of Single-Family Mortgage Default Resolutions." Real Estate Economics, 1998, 26 (3), pp. 391-429.

Ambrose, Brent W. and Capone, Charles A. "The Hazard Rates of First and Second Default." Journal of Real Estate Finance and Economics, 2000, 20 (2), pp.275-293.

Archer, Wayne R.; Ling, David C. and McGill, Gary A. "The Effect of Income and Collateral Constraints on Residential Mortgage Terminations." Regional Science and Urban Economics, 1996, 26, pp. 235-261.

Archer, Wayne R., Ling; David C. and McGill, Gary A. "Prepayment Risks and Lower Income Mortgage Borrowers.” University of Florida Working Paper, 2001.

Avery, Robert; Bostic, Raphael; Calem, Paul and Canner, Glenn. "Credit Risk, Credit Scoring, and the Performance of Home Mortgages." Federal Reserve Bulletin, 1996, 82 (7), pp. 621-648.

Bennett, P.; Peach, R. and Peristiani, S. "Structural Change in the Mortgage Market and the Propensity to Refinance.” Journal of Money Credit and Banking, 2001, 33 (4), pp. 955-975.

Berkovec, James A.; Canner, Glenn B.; Gabriel, Stuart A. and Hannan, Timothy H. "Race, Redlining, and Residential Mortgage Loan Performance." Journal of Real Estate Finance and Economics, 1994, 9, pp. 263-294.

Berkovec, James A.; Canner, Glenn B.; Gabriel, Stuart A. and Hannan, Timothy H. "Discrimination, Competition, and Loan Performance in FHA Mortgage Lending." Review of Economics and Statistics, 1998, pp.241-250.

Bradley, Michael; Gabriel, Stuart and Wohar, Mark. "The Thrift Crisis, Mortgage Credit Intermediation, and Housing Activity." Journal of Money, Credit, and Banking, 1995.

Canner, Glenn B.; Passmore, Wayne and Smith, Delores S. "Residential Lending to LowIncome and Minority Families: Evidence from the 1992 HMDA Data." Federal Reserve Bulletin 1994, 80.

Cotterman, Robert F. Neighborhood Effects in Mortgage Default Risk, U.S. Department of Housing and Urban Development, Office of Policy Development and Research, 2001.

Cox, D. R., "Regression Models and Life-Tables", Journal of the Royal Statistical Society, 1972, 34 (2), pp. 187-220.

Coulson, Edward. "Why are Hispanic- and Asian-American Homeownership Rates So Low?: Immigration and Other Factors." Journal of Urban Economics, 1999, 45, pp. 209-227.

Deng, Yongheng and Quigley, John M. "Woodhead Behavior and the Pricing of Residential Mortgages." Lusk Center for Real Estate Working Paper Series, University of Southern California, 2001. 
Deng, Yongheng; Quigley, John M. and Van Order, Robert. "Mortgage Default and Low Downpayment Loans: The Costs of Public Subsidy." Regional Science and Urban Economics, 1996, 26 (3-4), pp. 263-285.

Deng, Yongheng; Quigley, John M. and Van Order, Robert. "Mortgage Terminations, Heterogeneity and the Exercise of Mortgage Options." Econometrica, 2000, 68 (2), pp. 275-307.

Gabriel, Stuart and Rosenthal, Stuart. "Credit Rationing, Race, and the Mortgage Market." Journal of Urban Economics, 1991, 29 (3), pp. 371-379.

Galster, George. "The Facts of Lending Discrimination Cannot Be Argued Away by Examining Default Rates.” Housing Policy Debate, 1993, 4(1), 141-146.

Goering John and Wienk, Ron, eds. Mortgage Lending, Racial Discrimination, and Federal Policy, Urban Institute Press, 1996.

Green, J. and Shoven, J. B. "The Effect of Interest Rates on Mortgage Prepayment." Journal of Money, Credit and Banking, 1986, 18, pp. 41-50.

Han, A. K. and Hausman, J. A. "Flexible Parametric Estimation of Durationduration and Competing Risk Models." Journal of Applied Econometrics, 1990, 5(1), pp. 1-28.

Hayre, Lakhbir, ed. Salomon Smith Barney Guide to Mortgage-Backed And Asset-Backed Securities, John Wiley \& Sons, Inc., 2001.

Hendershott, P. and Van Order, R. "Pricing Mortgages: An Interpretation of Models and Results." Journal of Financial Services Research, 1987, 1, pp. 77-111.

Hilliard, Jimmy E.; Kau, James B. and Slawson, Carlos V. Jr. "Valuing Prepayment and Default in a Fixed-Rate Mortgage: A Bivariate Binomial Options Pricing Technique." Real Estate Economics, 1998, 26 (3), pp. 431-468.

Kain, John F. and Quigley, John M. "Housing Market Discrimination, Homeownership, and Savings Behavior." American Economic Review, 1972, 62, pp. 263-277.

Kau, James B. and Keenan, Donald C. "An Overview of Option-Theoretic Pricing of Mortgages.” Journal of Housing Research, 1995, 6 (2), pp. 217-244.

Kau, James B.; Keenan, Donald C.; Muller, Walter J. III and Epperson, James F. "A Generalized Valuation Model for Fixed-Rate Residential Mortgages." Journal of Money, Credit and Banking, 1992, 24, pp. 279-299.

Munnell, Alicia H.; Tootell, Geoffrey M. B.; Browne, Lynn E. and McEneaney, James. "Mortgage Lending in Boston: Interpreting HMDA Data." American Economic Review, 1996, 86, pp. 25-53.

Ondrich, Jan; Ross, Stephen L. and Yinger, John. "How common is housing discrimination? Improving on traditional measures.” Journal of Urban Economics, 2000, 47 (3), pp. 470-500.

Painter, Gary; Gabriel, Stuart A. and Myers, Dowell. "Race, Immigrant Status, and Housing Tenure Choice.” Journal of Urban Economics, 2001, 49 (1), pp. 150-167. 
Pennington-Cross, Anthony and Nichols, Joseph. "Credit History and the FHA-Conventional Choice," Real Estate Economics, 2000, 28 (2), pp. 307-336.

Quigley, John M. "Interest Rate Variations, Mortgage Prepayments and Household Mobility." Review of Economics and Statistics, 1987, 69, pp. 636-643.

Rosenthal, Stuart S. "Eliminating Credit Barriers to Increase Homeownership: How Far Can We Go?" Harvard University Joint Center for Housing Studies Working Paper, LIHO.01-3, 2001.

Schwartz, Edward S. and Torous, Water N. "Mortgage Prepayment and Default Decisions: A Poisson Regression Approach." Journal of the American Real Estate and Urban Economics Association, 1993, 21(4), pp. 431-449.

Stanton, Richard and Wallace, Nancy. "Mortgage Choice: What's the Point?" Real Estate Economics 1998, 26(2), pp. 173-206.

Van Order, Robert and Zorn, Peter. "The Performance of Low Income and Minority Mortgages: A Tale of Two Options." Freddie Mac Working Paper, 2001.

Yezer, Anthony M. "Biases in Tests for Redlining by Lenders," in Anthony M. Yezer, ed., Fair Lending Analysis. American Bankers Association, 1995, pp. 13-22.

Yinger, John. "Measuring Racial Discrimination with Fair Housing Audits: Caught in the Act." American Economic Review, 1986, 76, pp. 881-893.

Yinger, John. "Discrimination in Mortgage Lending: A Literature Review," in J.M. Goering and R. Wienk, eds., Mortgage Lending Discrimination: Research and Enforcement Concerns. The Urban Institute Press, 1996, pp. 29-73. 
TABLE 1-MEANS AND VARIANCES OF TIME-CONSTANT VARIABLES

\begin{tabular}{|c|c|c|c|}
\hline Variables & $\begin{array}{c}\text { Means } \\
\text { (Variances) }\end{array}$ & Variables & $\begin{array}{c}\text { Means } \\
\text { (Variances) }\end{array}$ \\
\hline $\begin{array}{l}\text { Credit Scores }<620 \\
\text { (categorical variable) }\end{array}$ & $\begin{array}{l}0.1874 \\
(0.158)\end{array}$ & $\begin{array}{l}\text { Mortgage Term }<30 \text { Years } \\
\text { (categorical variable) }\end{array}$ & $\begin{array}{l}0.0380 \\
(0.038)\end{array}$ \\
\hline $\begin{array}{l}\text { Credit Scores } 620 \sim 680 \\
\text { (categorical variable) }\end{array}$ & $\begin{array}{l}0.3098 \\
(0.224)\end{array}$ & $\begin{array}{l}\text { Central City Location } \\
\text { (categorical variable) }\end{array}$ & $\begin{array}{l}0.4405 \\
(0.262)\end{array}$ \\
\hline $\begin{array}{l}\text { Credit Scores } 680 \sim 740 \\
\text { (categorical variable) }\end{array}$ & $\begin{array}{l}0.3161 \\
(0.228)\end{array}$ & $\begin{array}{l}\text { Rural } \\
\text { (categorical variable) }\end{array}$ & $\begin{array}{l}0.0662 \\
(0.064)\end{array}$ \\
\hline $\begin{array}{l}\text { Black } \\
\text { (categorical variable) }\end{array}$ & $\begin{array}{l}0.1240 \\
(0.117)\end{array}$ & $\begin{array}{l}\text { First Time Home Buyer } \\
\text { (categorical variable) }\end{array}$ & $\begin{array}{l}0.6711 \\
(0.244)\end{array}$ \\
\hline $\begin{array}{l}\text { Asian } \\
\text { (categorical variable) }\end{array}$ & $\begin{array}{l}0.0168 \\
(0.019)\end{array}$ & $\begin{array}{l}\text { New House } \\
\text { (categorical variable) }\end{array}$ & $\begin{array}{l}0.0789 \\
(0.077)\end{array}$ \\
\hline $\begin{array}{l}\text { Hispanic } \\
\text { (categorical variable) }\end{array}$ & $\begin{array}{l}0.1214 \\
(0.130)\end{array}$ & $\begin{array}{l}\text { Unmarried Co-borrower } \\
\text { (categorical variable) }\end{array}$ & $\begin{array}{l}0.1114 \\
(0.103)\end{array}$ \\
\hline $\begin{array}{l}\text { Others } \\
\text { (categorical variable) }\end{array}$ & $\begin{array}{l}0.0205 \\
(0.023)\end{array}$ & $\begin{array}{l}\text { Single Male } \\
\text { (categorical variable) }\end{array}$ & $\begin{array}{l}0.1936 \\
(0.162)\end{array}$ \\
\hline Loan-to-Value Ratio & $\begin{array}{l}0.9383 \\
(0.034)\end{array}$ & $\begin{array}{l}\text { Single Female } \\
\text { (categorical variable) }\end{array}$ & $\begin{array}{l}0.2022 \\
(0.168)\end{array}$ \\
\hline $\begin{array}{l}\text { Housing Exp. to Income Ratio } \\
20 \sim 38 \% \text { (categorical variable) }\end{array}$ & $\begin{array}{l}0.6447 \\
(0.254)\end{array}$ & Number of Dependents & $\begin{array}{l}0.7692 \\
(1.288)\end{array}$ \\
\hline $\begin{array}{l}\text { Housing Exp. to Income Ratio } \\
>38 \% \text { (categorical variable) }\end{array}$ & $\begin{array}{l}0.0103 \\
(0.011)\end{array}$ & $\begin{array}{l}\text { Log Value of Liquid } \\
\text { Assets }\end{array}$ & $\begin{array}{l}8.4707 \\
(4.966)\end{array}$ \\
\hline $\begin{array}{l}\text { Debt to Income Ratio } \\
20 \sim 41 \% \text { (categorical variable) }\end{array}$ & $\begin{array}{l}0.8041 \\
(0.187)\end{array}$ & $\begin{array}{l}\text { Borrower Age }<25 \\
\text { (categorical variable) }\end{array}$ & $\begin{array}{l}0.1101 \\
(0.101)\end{array}$ \\
\hline $\begin{array}{l}\text { Debt to Income Ratio } \\
41 \sim 53 \% \text { (categorical variable) }\end{array}$ & $\begin{array}{l}0.1577 \\
(0.137)\end{array}$ & $\begin{array}{l}\text { Borrower Age } 25 \sim 35 \\
\text { (categorical variable) }\end{array}$ & $\begin{array}{l}0.4977 \\
(0.267)\end{array}$ \\
\hline $\begin{array}{l}\text { Debt to Income Ratio } \\
>53 \% \text { (categorical variable) }\end{array}$ & $\begin{array}{l}0.0084 \\
(0.009)\end{array}$ & $\begin{array}{l}\text { Borrower Age } 35 \sim 45 \\
\text { (categorical variable) }\end{array}$ & $\begin{array}{l}0.2614 \\
(0.204)\end{array}$ \\
\hline $\begin{array}{l}\text { Buydown } \\
\text { (categorical variable) }\end{array}$ & $\begin{array}{l}0.0242 \\
(0.025)\end{array}$ & $\begin{array}{l}\text { Log Value of Household } \\
\text { Income }\end{array}$ & $\begin{array}{l}8.0379 \\
(2.340)\end{array}$ \\
\hline $\begin{array}{l}\text { Log of Property Appraisal } \\
\text { Value }\end{array}$ & $\begin{array}{l}11.2102 \\
(4.423)\end{array}$ & & \\
\hline \multicolumn{2}{|l|}{ Number of Observations } & \multicolumn{2}{|l|}{12,021} \\
\hline
\end{tabular}

Note: Variances are in parentheses. 
TABle 2-MEANS AND VARIANCES OF TIME-VARYING VARIABLES At ORIGINATION AND TERMINATION

\begin{tabular}{|c|c|c|c|c|c|c|}
\hline \multirow[t]{2}{*}{ Variables } & \multicolumn{4}{|c|}{ At Origination } & \multicolumn{2}{|c|}{ At Termination } \\
\hline & All Loans & Prepaid & Defaulted & Other* & Prepaid & Defaulted \\
\hline $\begin{array}{l}\text { Call Option (fraction of contract } \\
\text { Value) }\end{array}$ & $\begin{array}{r}-0.0120 \\
(0.007)\end{array}$ & $\begin{array}{l}0.0001 \\
(0.007)\end{array}$ & $\begin{array}{l}-0.0022 \\
(0.005)\end{array}$ & $\begin{array}{l}-0.0265 \\
(0.008)\end{array}$ & $\begin{array}{l}0.0750 \\
(0.007)\end{array}$ & $\begin{array}{l}0.0352 \\
(0.005)\end{array}$ \\
\hline $\begin{array}{l}\text { Put Option (probability of } \\
\text { negative equity) }\end{array}$ & $\begin{array}{l}0.2732 \\
(0.057)\end{array}$ & $\begin{array}{l}0.2694 \\
(0.051)\end{array}$ & $\begin{array}{l}0.2160 \\
(0.062)\end{array}$ & $\begin{array}{l}0.2869 \\
(0.061)\end{array}$ & $\begin{array}{l}0.0407 \\
(0.013)\end{array}$ & $\begin{array}{l}0.1011 \\
(0.034)\end{array}$ \\
\hline $\begin{array}{l}\text { SMSA Unemployment Rate } \\
\text { (percent) }\end{array}$ & $\begin{array}{l}5.6901 \\
(7.498)\end{array}$ & $\begin{array}{l}5.7902 \\
(5.526)\end{array}$ & $\begin{array}{c}4.2433 \\
(12.690)\end{array}$ & $\begin{array}{l}5.8291 \\
(8.333)\end{array}$ & $\begin{array}{l}4.2383 \\
(4.120)\end{array}$ & $\begin{array}{l}3.4211 \\
(8.283)\end{array}$ \\
\hline $\begin{array}{l}\text { Log Value of Herfindahl- } \\
\text { Hirschmann Index }\end{array}$ & $\begin{array}{l}5.8737 \\
(1.500)\end{array}$ & $\begin{array}{l}6.1111 \\
(0.666)\end{array}$ & $\begin{array}{l}3.7181 \\
(6.669)\end{array}$ & $\begin{array}{l}5.9866 \\
(0.649)\end{array}$ & $\begin{array}{l}5.9782 \\
(0.494)\end{array}$ & $\begin{array}{l}3.6548 \\
(6.556)\end{array}$ \\
\hline $\begin{array}{l}\text { Log Value of HH Index } \\
\text { For Blacks }\end{array}$ & $\begin{array}{l}0.7038 \\
(3.803)\end{array}$ & $\begin{array}{l}0.4738 \\
(2.714)\end{array}$ & $\begin{array}{l}0.8284 \\
(4.190)\end{array}$ & $\begin{array}{l}0.9277 \\
(4.789)\end{array}$ & $\begin{array}{l}0.4672 \\
(2.631)\end{array}$ & $\begin{array}{l}0.8184 \\
(4.113)\end{array}$ \\
\hline $\begin{array}{l}\text { Log Value of HH Index } \\
\text { For Hispanics }\end{array}$ & $\begin{array}{l}0.6968 \\
(4.316)\end{array}$ & $\begin{array}{l}0.4967 \\
(3.092)\end{array}$ & $\begin{array}{l}0.6857 \\
(3.812)\end{array}$ & $\begin{array}{l}0.9118 \\
(5.617)\end{array}$ & $\begin{array}{l}0.4875 \\
(2.961)\end{array}$ & $\begin{array}{l}0.6760 \\
(3.727)\end{array}$ \\
\hline Number of Observations & 12,021 & 5,730 & 913 & 5,378 & 5,730 & 913 \\
\hline
\end{tabular}

Note: Variances are in parentheses.

*Other includes those outstanding at the end of the observation period. 
TABLE 3-MAXIMUM LIKELIHOOD ESTIMATES FOR COMPETING RISKS

of FHA MORTGAGE PREPAYMENT AND DEFAULT

\begin{tabular}{|c|c|c|c|c|c|c|}
\hline & \multicolumn{2}{|c|}{ Model 1} & \multicolumn{2}{|c|}{ Model 2} & \multicolumn{2}{|c|}{ Model 3} \\
\hline & Prepay & Default & Prepay & Default & Prepay & Default \\
\hline $\begin{array}{l}\text { Call Option (fraction of } \\
\text { Contract value) }\end{array}$ & & & $\begin{array}{c}4.904 \\
(27.085)\end{array}$ & $\begin{array}{l}2.414 \\
(3.846)\end{array}$ & & \\
\hline $\begin{array}{l}\text { Put Option (probability } \\
\text { of negative equity) }\end{array}$ & & & $\begin{array}{c}-1.689 \\
(12.508)\end{array}$ & $\begin{array}{c}1.802 \\
(6.643)\end{array}$ & & \\
\hline $\begin{array}{l}\text { Interaction of Call Option } \\
\text { Credit Scores }<620\end{array}$ & & & & & $\begin{array}{c}4.491 \\
(10.577)\end{array}$ & $\begin{array}{r}2.478 \\
(2.264)\end{array}$ \\
\hline $\begin{array}{l}\text { Interaction of Call Option } \\
\text { Credit Scores } 620 \sim 680\end{array}$ & & & & & $\begin{array}{c}4.135 \\
(13.086)\end{array}$ & $\begin{array}{c}1.741 \\
(1.794)\end{array}$ \\
\hline $\begin{array}{l}\text { Interaction of Call Option } \\
\text { Credit Scores } 680 \sim 740\end{array}$ & & & & & $\begin{array}{c}5.359 \\
(18.058)\end{array}$ & $\begin{array}{l}1.859 \\
(1.520)\end{array}$ \\
\hline $\begin{array}{l}\text { Interaction of Call Option } \\
\text { Credit Scores }>740\end{array}$ & & & & & $\begin{array}{c}5.867 \\
(15.990)\end{array}$ & $\begin{array}{c}2.625 \\
(1.399)\end{array}$ \\
\hline $\begin{array}{l}\text { Interaction of Put Option } \\
\text { Credit Scores }<620\end{array}$ & & & & & $\begin{array}{l}-2.747 \\
(6.751)\end{array}$ & $\begin{array}{r}2.278 \\
(4.762)\end{array}$ \\
\hline $\begin{array}{l}\text { Interaction of Put Option } \\
\text { Credit Scores } 620 \sim 680\end{array}$ & & & & & $\begin{array}{l}-2.441 \\
(9.044)\end{array}$ & $\begin{array}{c}1.705 \\
(4.349)\end{array}$ \\
\hline $\begin{array}{l}\text { Interaction of Put Option } \\
\text { Credit Scores } 680 \sim 740\end{array}$ & & & & & $\begin{array}{l}-1.684 \\
(8.189)\end{array}$ & $\begin{array}{c}2.048 \\
(4.638)\end{array}$ \\
\hline $\begin{array}{l}\text { Interaction of Put Option } \\
\text { Credit Scores }>740\end{array}$ & & & & & $\begin{array}{l}-0.935 \\
(4.468)\end{array}$ & $\begin{array}{c}2.173 \\
(2.964)\end{array}$ \\
\hline $\begin{array}{l}\text { SMSA Unemployment } \\
\text { Rate (percent) }\end{array}$ & $\begin{array}{c}-0.131 \\
(17.493)\end{array}$ & $\begin{array}{c}0.108 \\
(5.470)\end{array}$ & $\begin{array}{c}-0.108 \\
(13.567)\end{array}$ & $\begin{array}{c}0.054 \\
(2.383)\end{array}$ & $\begin{array}{c}-0.107 \\
(13.457)\end{array}$ & $\begin{array}{c}0.054 \\
(2.409)\end{array}$ \\
\hline $\begin{array}{l}\text { Log Value of Herfindahl } \\
\text { Hirschmann Index }\end{array}$ & $\begin{array}{c}0.031 \\
(1.093)\end{array}$ & $\begin{array}{l}-0.429 \\
(3.288)\end{array}$ & $\begin{array}{c}0.006 \\
(0.216)\end{array}$ & $\begin{array}{l}-0.393 \\
(2.994)\end{array}$ & $\begin{array}{l}-0.003 \\
(0.104)\end{array}$ & $\begin{array}{l}-0.384 \\
(2.895)\end{array}$ \\
\hline $\begin{array}{l}\text { Interaction of Black } \\
\text { and Log of H-H Index }\end{array}$ & $\begin{array}{c}0.192 \\
(1.787)\end{array}$ & $\begin{array}{l}-0.220 \\
(0.819)\end{array}$ & $\begin{array}{c}0.156 \\
(1.434)\end{array}$ & $\begin{array}{l}-0.255 \\
(0.954)\end{array}$ & $\begin{array}{c}0.151 \\
(1.387)\end{array}$ & $\begin{array}{l}-0.238 \\
(0.883)\end{array}$ \\
\hline $\begin{array}{l}\text { Interaction of Hispanic } \\
\text { and Log of H-H Index }\end{array}$ & $\begin{array}{c}0.128 \\
(1.175)\end{array}$ & $\begin{array}{l}-0.263 \\
(0.832)\end{array}$ & $\begin{array}{c}0.224 \\
(2.060)\end{array}$ & $\begin{array}{l}-0.124 \\
(0.385)\end{array}$ & $\begin{array}{c}0.242 \\
(2.210)\end{array}$ & $\begin{array}{l}-0.160 \\
(0.493)\end{array}$ \\
\hline $\begin{array}{l}\text { Credit Scores }<620 \\
\text { (dummy) }\end{array}$ & & & & & $\begin{array}{l}-0.005 \\
(0.079)\end{array}$ & $\begin{array}{c}1.684 \\
(5.302)\end{array}$ \\
\hline $\begin{array}{l}\text { Credit Scores 620 680 } \\
\text { (dummy) }\end{array}$ & & & & & $\begin{array}{c}0.055 \\
(1.061)\end{array}$ & $\begin{array}{r}1.366 \\
(4.522)\end{array}$ \\
\hline $\begin{array}{l}\text { Credit Scores 680 740 } \\
\text { (dummy) }\end{array}$ & & & & & $\begin{array}{c}0.013 \\
(0.254)\end{array}$ & $\begin{array}{c}0.729 \\
(2.290)\end{array}$ \\
\hline
\end{tabular}


TABLE 3-Continued.

\begin{tabular}{|c|c|c|c|c|c|c|}
\hline & \multicolumn{2}{|c|}{ Model 1} & \multicolumn{2}{|c|}{ Model 2} & \multicolumn{2}{|c|}{ Model 3} \\
\hline & Prepay & Default & Prepay & Default & Prepay & Default \\
\hline Black (dummy) & $\begin{array}{l}-1.527 \\
(2.514)\end{array}$ & $\begin{array}{l}1.921 \\
(1.280)\end{array}$ & $\begin{array}{l}-1.400 \\
(2.283)\end{array}$ & $\begin{array}{l}2.123 \\
(1.416)\end{array}$ & $\begin{array}{l}-1.344 \\
(2.188)\end{array}$ & $\begin{array}{c}1.770 \\
(1.171)\end{array}$ \\
\hline Asian (dummy) & $\begin{array}{l}-0.072 \\
(0.772)\end{array}$ & $\begin{array}{l}-0.062 \\
(0.149)\end{array}$ & $\begin{array}{l}-0.007 \\
(0.067)\end{array}$ & $\begin{array}{l}-0.168 \\
(0.393)\end{array}$ & $\begin{array}{c}0.001 \\
(0.015)\end{array}$ & $\begin{array}{l}-0.189 \\
(0.408)\end{array}$ \\
\hline Hispanic (dummy) & $\begin{array}{l}-0.944 \\
(1.538)\end{array}$ & $\begin{array}{c}1.777 \\
(0.995)\end{array}$ & $\begin{array}{l}-1.555 \\
(2.533)\end{array}$ & $\begin{array}{c}0.941 \\
(0.515)\end{array}$ & $\begin{array}{l}-1.645 \\
(2.665)\end{array}$ & $\begin{array}{c}1.052 \\
(0.573)\end{array}$ \\
\hline Others (dummy) & $\begin{array}{l}-0.241 \\
(2.437)\end{array}$ & $\begin{array}{c}0.196 \\
(0.640)\end{array}$ & $\begin{array}{l}-0.354 \\
(3.542)\end{array}$ & $\begin{array}{c}0.078 \\
(0.258)\end{array}$ & $\begin{array}{l}-0.317 \\
(3.161)\end{array}$ & $\begin{array}{l}-0.114 \\
(0.377)\end{array}$ \\
\hline Loan-to-Value Ratio & $\begin{array}{l}-1.483 \\
(7.730)\end{array}$ & $\begin{array}{l}1.994 \\
(2.179)\end{array}$ & $\begin{array}{l}-1.330 \\
(7.135)\end{array}$ & $\begin{array}{c}2.499 \\
(2.687)\end{array}$ & $\begin{array}{l}-1.354 \\
(7.235)\end{array}$ & $\begin{array}{l}2.348 \\
(2.469)\end{array}$ \\
\hline $\begin{array}{l}\text { Housing Exp. to Income } \\
20 \sim 38 \% \text { (dummy) }\end{array}$ & $\begin{array}{c}0.236 \\
(5.923)\end{array}$ & $\begin{array}{c}0.180 \\
(1.121)\end{array}$ & $\begin{array}{c}0.221 \\
(5.293)\end{array}$ & $\begin{array}{l}-0.203 \\
(1.178)\end{array}$ & $\begin{array}{c}0.230 \\
(5.477)\end{array}$ & $\begin{array}{l}-0.191 \\
(1.074)\end{array}$ \\
\hline $\begin{array}{l}\text { Housing Exp. to Income } \\
>38 \% \text { (dummy) }\end{array}$ & $\begin{array}{c}0.327 \\
(2.281)\end{array}$ & $\begin{array}{c}0.035 \\
(0.063)\end{array}$ & $\begin{array}{c}0.050 \\
(0.336)\end{array}$ & $\begin{array}{l}-0.083 \\
(0.150)\end{array}$ & $\begin{array}{c}0.043 \\
(0.293)\end{array}$ & $\begin{array}{c}0.108 \\
(0.191)\end{array}$ \\
\hline $\begin{array}{l}\text { Debt to Income Ratio } \\
20 \sim 41 \% \text { (dummy) }\end{array}$ & $\begin{array}{c}0.109 \\
(1.428)\end{array}$ & $\begin{array}{l}-0.253 \\
(0.756)\end{array}$ & $\begin{array}{c}0.004 \\
(0.054)\end{array}$ & $\begin{array}{l}-0.261 \\
(0.777)\end{array}$ & $\begin{array}{c}0.009 \\
(0.111)\end{array}$ & $\begin{array}{l}-0.398 \\
(1.182)\end{array}$ \\
\hline $\begin{array}{l}\text { Debt to Income Ratio } \\
41 \sim 53 \% \text { (dummy) }\end{array}$ & $\begin{array}{l}0.220 \\
(2.647)\end{array}$ & $\begin{array}{l}-0.044 \\
(0.126)\end{array}$ & $\begin{array}{c}0.083 \\
(0.990)\end{array}$ & $\begin{array}{l}-0.061 \\
(0.174)\end{array}$ & $\begin{array}{c}0.103 \\
(1.205)\end{array}$ & $\begin{array}{l}-0.281 \\
(0.793)\end{array}$ \\
\hline $\begin{array}{l}\text { Debt to Income Ratio } \\
>53 \% \text { (dummy) }\end{array}$ & $\begin{array}{c}0.282 \\
(1.735)\end{array}$ & $\begin{array}{l}-0.519 \\
(0.735)\end{array}$ & $\begin{array}{c}0.032 \\
(0.203)\end{array}$ & $\begin{array}{l}-0.593 \\
(0.834)\end{array}$ & $\begin{array}{c}0.049 \\
(0.304)\end{array}$ & $\begin{array}{l}-0.857 \\
(1.209)\end{array}$ \\
\hline $\begin{array}{l}\text { Buydown } \\
\text { (dummy) }\end{array}$ & $\begin{array}{c}0.247 \\
(3.235)\end{array}$ & $\begin{array}{c}0.080 \\
(0.267)\end{array}$ & $\begin{array}{c}0.167 \\
(2.179)\end{array}$ & $\begin{array}{l}-0.064 \\
(0.208)\end{array}$ & $\begin{array}{c}0.161 \\
(2.111)\end{array}$ & $\begin{array}{l}-0.012 \\
(0.039)\end{array}$ \\
\hline $\begin{array}{l}\text { Log Value of Property } \\
\text { Appraisal Value }\end{array}$ & $\begin{array}{l}-0.109 \\
(1.820)\end{array}$ & $\begin{array}{c}0.160 \\
(0.759)\end{array}$ & $\begin{array}{c}0.206 \\
(3.313)\end{array}$ & $\begin{array}{c}0.319 \\
(1.444)\end{array}$ & $\begin{array}{c}0.202 \\
(3.243)\end{array}$ & $\begin{array}{c}0.335 \\
(1.489)\end{array}$ \\
\hline $\begin{array}{l}\text { Mortgage Term }<30 \text { Year } \\
\text { (dummy) }\end{array}$ & $\begin{array}{l}-0.300 \\
(4.386)\end{array}$ & $\begin{array}{l}-1.094 \\
(2.418)\end{array}$ & $\begin{array}{l}-0.036 \\
(0.518)\end{array}$ & $\begin{array}{l}-0.864 \\
(1.896)\end{array}$ & $\begin{array}{l}-0.044 \\
(0.624)\end{array}$ & $\begin{array}{l}-0.820 \\
(1.761)\end{array}$ \\
\hline $\begin{array}{l}\text { Central City Location } \\
\text { (dummy) }\end{array}$ & $\begin{array}{c}0.035 \\
(1.327)\end{array}$ & $\begin{array}{l}-0.151 \\
(1.546)\end{array}$ & $\begin{array}{c}0.040 \\
(1.497)\end{array}$ & $\begin{array}{l}-0.155 \\
(1.572)\end{array}$ & $\begin{array}{c}0.042 \\
(1.560)\end{array}$ & $\begin{array}{l}-0.141 \\
(1.407)\end{array}$ \\
\hline $\begin{array}{l}\text { Rural } \\
\text { (dummy) }\end{array}$ & $\begin{array}{c}0.037 \\
(0.678)\end{array}$ & $\begin{array}{l}-0.256 \\
(1.138)\end{array}$ & $\begin{array}{c}0.041 \\
(0.735)\end{array}$ & $\begin{array}{l}-0.297 \\
(1.346)\end{array}$ & $\begin{array}{c}0.043 \\
(0.770)\end{array}$ & $\begin{array}{l}-0.244 \\
(1.088)\end{array}$ \\
\hline $\begin{array}{l}\text { First Time Home Buyer } \\
\text { (dummy) }\end{array}$ & $\begin{array}{l}-0.183 \\
(6.504)\end{array}$ & $\begin{array}{c}0.126 \\
(1.151)\end{array}$ & $\begin{array}{l}-0.193 \\
(6.827)\end{array}$ & $\begin{array}{c}0.121 \\
(1.098)\end{array}$ & $\begin{array}{l}-0.186 \\
(6.557)\end{array}$ & $\begin{array}{c}0.058 \\
(0.525)\end{array}$ \\
\hline $\begin{array}{l}\text { New House } \\
\text { (dummy) }\end{array}$ & $\begin{array}{c}-0.132 \\
(2.767)\end{array}$ & $\begin{array}{c}-0.103 \\
(0.543)\end{array}$ & $\begin{array}{l}-0.036 \\
(0.738)\end{array}$ & $\begin{array}{l}-0.067 \\
(0.350)\end{array}$ & $\begin{array}{l}-0.040 \\
(0.812)\end{array}$ & $\begin{array}{l}-0.043 \\
(0.223)\end{array}$ \\
\hline
\end{tabular}


TABLE 3-Continued.

\begin{tabular}{|c|c|c|c|c|c|c|}
\hline & \multicolumn{2}{|c|}{ Model 1} & \multicolumn{2}{|c|}{ Model 2} & \multicolumn{2}{|c|}{ Model 3} \\
\hline & Prepay & Default & Prepay & Default & Prepay & Default \\
\hline $\begin{array}{l}\text { Unmarried Co-borrower } \\
\text { (dummy) }\end{array}$ & $\begin{array}{l}-0.006 \\
(0.133)\end{array}$ & $\begin{array}{l}-0.108 \\
(0.604)\end{array}$ & $\begin{array}{l}-0.008 \\
(0.178)\end{array}$ & $\begin{array}{l}-0.115 \\
(0.642)\end{array}$ & $\begin{array}{l}-0.012 \\
(0.285)\end{array}$ & $\begin{array}{l}-0.077 \\
(0.426)\end{array}$ \\
\hline $\begin{array}{l}\text { Single Male } \\
\text { (dummy) }\end{array}$ & $\begin{array}{c}0.017 \\
(0.473)\end{array}$ & $\begin{array}{l}0.306 \\
(2.416)\end{array}$ & $\begin{array}{l}-0.007 \\
(0.195)\end{array}$ & $\begin{array}{c}0.332 \\
(2.612)\end{array}$ & $\begin{array}{l}-0.005 \\
(0.128)\end{array}$ & $\begin{array}{c}0.299 \\
(2.323)\end{array}$ \\
\hline $\begin{array}{l}\text { Single Female } \\
\text { (dummy) }\end{array}$ & $\begin{array}{l}-0.088 \\
(2.225)\end{array}$ & $\begin{array}{l}-0.189 \\
(1.289)\end{array}$ & $\begin{array}{l}-0.105 \\
(2.658)\end{array}$ & $\begin{array}{l}-0.158 \\
(1.073)\end{array}$ & $\begin{array}{l}-0.105 \\
(2.629)\end{array}$ & $\begin{array}{l}-0.180 \\
(1.206)\end{array}$ \\
\hline Number of Dependents & $\begin{array}{l}-0.071 \\
(5.345)\end{array}$ & $\begin{array}{c}0.133 \\
(3.228)\end{array}$ & $\begin{array}{l}-0.084 \\
(6.291)\end{array}$ & $\begin{array}{c}0.123 \\
(3.008)\end{array}$ & $\begin{array}{l}-0.076 \\
(5.700)\end{array}$ & $\begin{array}{c}0.078 \\
(1.822)\end{array}$ \\
\hline $\begin{array}{l}\text { Log Value of Liquid } \\
\text { Assets }\end{array}$ & $\begin{array}{c}0.006 \\
(0.699)\end{array}$ & $\begin{array}{l}-0.091 \\
(3.008)\end{array}$ & $\begin{array}{c}0.017 \\
(1.935)\end{array}$ & $\begin{array}{l}-0.094 \\
(3.087)\end{array}$ & $\begin{array}{c}0.013 \\
(1.526)\end{array}$ & $\begin{array}{l}-0.068 \\
(2.104)\end{array}$ \\
\hline $\begin{array}{l}\text { Borrower Age }<25 \\
\text { (dummy) }\end{array}$ & $\begin{array}{c}0.415 \\
(7.459)\end{array}$ & $\begin{array}{c}0.240 \\
(1.303)\end{array}$ & $\begin{array}{c}0.442 \\
(7.883)\end{array}$ & $\begin{array}{c}0.306 \\
(1.651)\end{array}$ & $\begin{array}{c}0.444 \\
(7.926)\end{array}$ & $\begin{array}{c}0.205 \\
(1.092)\end{array}$ \\
\hline $\begin{array}{l}\text { Borrower Age } 25 \sim 35 \\
\text { (dummy) }\end{array}$ & $\begin{array}{c}0.245 \\
(5.693)\end{array}$ & $\begin{array}{l}-0.192 \\
(1.282)\end{array}$ & $\begin{array}{c}0.280 \\
(6.421)\end{array}$ & $\begin{array}{l}-0.137 \\
(0.913)\end{array}$ & $\begin{array}{c}0.279 \\
(6.398)\end{array}$ & $\begin{array}{l}-0.192 \\
(1.258)\end{array}$ \\
\hline $\begin{array}{l}\text { Borrower Age 35 45 } \\
\text { (dummy) }\end{array}$ & $\begin{array}{c}0.057 \\
(1.234)\end{array}$ & $\begin{array}{l}-0.177 \\
(1.088)\end{array}$ & $\begin{array}{c}0.065 \\
(1.386)\end{array}$ & $\begin{array}{l}-0.112 \\
(0.687)\end{array}$ & $\begin{array}{c}0.064 \\
(1.351)\end{array}$ & $\begin{array}{l}-0.156 \\
(0.944)\end{array}$ \\
\hline $\begin{array}{l}\text { Log Value of Household } \\
\text { Income }\end{array}$ & $\begin{array}{c}0.597 \\
(9.142)\end{array}$ & $\begin{array}{l}-0.345 \\
(1.402)\end{array}$ & $\begin{array}{c}0.224 \\
(3.286)\end{array}$ & $\begin{array}{l}-0.628 \\
(2.429)\end{array}$ & $\begin{array}{c}0.239 \\
(3.494)\end{array}$ & $\begin{array}{l}-0.742 \\
(2.814)\end{array}$ \\
\hline Log Likelihood & \multicolumn{2}{|c|}{$-35,701$} & \multicolumn{2}{|c|}{$-35,247$} & \multicolumn{2}{|c|}{$-35,150$} \\
\hline
\end{tabular}

Note: T-ratios are in parentheses. All models are estimated by ML approach. Prepayment and default functions are considered as correlated competing risks and they are estimated jointly. Flexible baseline functions (following Han and Hausman, 1990) for prepayment and default are estimated simultaneously with the competing risks hazard functions. 
TABle 4-UnaduUsted Cumulative Probability Of PREPAyment AND DEFAUlt By VARIOUS COVARIATES AT THE END OF ONE-, THREE-, AND FIVE-YEAR

\begin{tabular}{|c|c|c|c|c|c|c|}
\hline & \multicolumn{3}{|c|}{ Prepayment } & \multicolumn{3}{|c|}{ Default } \\
\hline & $\begin{array}{l}\text { End of } \\
\text { Year1 }\end{array}$ & $\begin{array}{l}\text { End of } \\
\text { Year } 3\end{array}$ & $\begin{array}{l}\text { End of } \\
\text { Year5 }\end{array}$ & $\begin{array}{l}\text { End of } \\
\text { Year1 }\end{array}$ & $\begin{array}{l}\text { End of } \\
\text { Year } 3\end{array}$ & $\begin{array}{c}\text { End of } \\
\text { Year5 }\end{array}$ \\
\hline \multicolumn{7}{|l|}{ By Borrower Race } \\
\hline White & $2.33 \%$ & $22.77 \%$ & $39.65 \%$ & $0.46 \%$ & $2.21 \%$ & $3.30 \%$ \\
\hline Black & $1.39 \%$ & $14.12 \%$ & $24.78 \%$ & $1.03 \%$ & $5.77 \%$ & $8.77 \%$ \\
\hline Hispanic & $1.65 \%$ & $16.35 \%$ & $30.52 \%$ & $1.15 \%$ & $5.84 \%$ & $7.92 \%$ \\
\hline \multicolumn{7}{|l|}{ By Liquid Asset } \\
\hline Liquid Asset $\geq$ Median & $2.37 \%$ & $23.59 \%$ & $40.28 \%$ & $0.48 \%$ & $2.32 \%$ & $3.48 \%$ \\
\hline Liquid Asset $<$ Median & $2.00 \%$ & $18.43 \%$ & $33.33 \%$ & $0.74 \%$ & $3.82 \%$ & $5.51 \%$ \\
\hline \multicolumn{7}{|l|}{ By LTV } \\
\hline LTV $<95 \%$ & $2.68 \%$ & $21.61 \%$ & $37.75 \%$ & $0.59 \%$ & $2.76 \%$ & $4.01 \%$ \\
\hline $\mathrm{LTV} \geq 95 \%$ & $1.87 \%$ & $20.61 \%$ & $36.18 \%$ & $0.63 \%$ & $3.27 \%$ & $4.81 \%$ \\
\hline \multicolumn{7}{|l|}{ By Buyers' Type } \\
\hline Repeat Buyer & $3.26 \%$ & $24.74 \%$ & $41.18 \%$ & $0.56 \%$ & $2.56 \%$ & $3.83 \%$ \\
\hline First Time Buyer & $1.65 \%$ & $19.16 \%$ & $34.64 \%$ & $0.64 \%$ & $3.33 \%$ & $4.83 \%$ \\
\hline \multicolumn{7}{|l|}{ By Housing Expense Ratio } \\
\hline $20 \%<\mathrm{HEI} \leq 38 \%$ & $2.11 \%$ & $20.81 \%$ & $36.89 \%$ & $0.69 \%$ & $3.51 \%$ & $5.13 \%$ \\
\hline Otherwise & $2.31 \%$ & $21.35 \%$ & $36.61 \%$ & $0.46 \%$ & $2.28 \%$ & $3.37 \%$ \\
\hline \multicolumn{7}{|l|}{ By Credit Score } \\
\hline Credit Score $\geq 680$ & $2.51 \%$ & $23.36 \%$ & $40.02 \%$ & $0.22 \%$ & $1.33 \%$ & $2.34 \%$ \\
\hline Credit Score $<620$ & $1.66 \%$ & $17.99 \%$ & $31.38 \%$ & $1.36 \%$ & $6.39 \%$ & $8.67 \%$ \\
\hline \multicolumn{7}{|l|}{ By Risk Type } \\
\hline Low Credit Risk & $4.05 \%$ & $25.34 \%$ & $42.72 \%$ & $0.16 \%$ & $1.11 \%$ & $2.01 \%$ \\
\hline High Credit Risk & $1.66 \%$ & $16.04 \%$ & $29.00 \%$ & $1.09 \%$ & $5.40 \%$ & $6.95 \%$ \\
\hline
\end{tabular}

Note: Unadjusted probabilities are calculated based on cleaned full sample. 


\section{Table 5-Predicted Cumulative Probability Of Prepayment And Default Risks}

BY VARIOUS COVARIATES AT THE END OF ONE-, THREE-, AND FIVE-YEAR

\begin{tabular}{|c|c|c|c|c|c|c|c|c|c|}
\hline & \multicolumn{3}{|c|}{ Prepayment } & \multicolumn{3}{|c|}{ Default } & \multicolumn{3}{|c|}{ Total Termination } \\
\hline & $\begin{array}{l}\text { End of } \\
\text { Year1 }\end{array}$ & $\begin{array}{l}\text { End of } \\
\text { Year3 }\end{array}$ & $\begin{array}{l}\text { End of } \\
\text { Year } 5\end{array}$ & $\begin{array}{l}\text { End of } \\
\text { Year1 }\end{array}$ & $\begin{array}{l}\text { End of } \\
\text { Year } 3\end{array}$ & $\begin{array}{l}\text { End of } \\
\text { Year5 }\end{array}$ & $\begin{array}{l}\text { End of } \\
\text { Year1 }\end{array}$ & $\begin{array}{l}\text { End of } \\
\text { Year } 3\end{array}$ & $\begin{array}{l}\text { End of } \\
\text { Year5 }\end{array}$ \\
\hline \multicolumn{10}{|l|}{ By Borrower Race } \\
\hline White & $2.91 \%$ & $21.26 \%$ & $43.22 \%$ & $0.42 \%$ & $2.11 \%$ & $3.38 \%$ & $3.33 \%$ & $23.37 \%$ & $46.60 \%$ \\
\hline Black & $1.87 \%$ & $13.92 \%$ & $29.64 \%$ & $0.59 \%$ & $3.19 \%$ & $5.30 \%$ & $2.47 \%$ & $17.11 \%$ & $34.94 \%$ \\
\hline Hispanic & $2.39 \%$ & $17.30 \%$ & $36.02 \%$ & $0.46 \%$ & $2.42 \%$ & $3.96 \%$ & $2.85 \%$ & $19.72 \%$ & $39.97 \%$ \\
\hline \multicolumn{10}{|l|}{ By Liquid Asset } \\
\hline Liquid Asset $\geq$ Median & $2.77 \%$ & $20.25 \%$ & $41.46 \%$ & $0.42 \%$ & $2.13 \%$ & $3.42 \%$ & $3.19 \%$ & $22.38 \%$ & $44.89 \%$ \\
\hline Liquid Asset $<$ Median & $2.73 \%$ & $20.01 \%$ & $41.00 \%$ & $0.45 \%$ & $2.28 \%$ & $3.66 \%$ & $3.18 \%$ & $22.28 \%$ & $44.66 \%$ \\
\hline \multicolumn{10}{|l|}{ By LTV } \\
\hline LTV $<95 \%$ & $3.09 \%$ & $22.41 \%$ & $45.20 \%$ & $0.35 \%$ & $1.83 \%$ & $2.99 \%$ & $3.45 \%$ & $24.24 \%$ & $48.19 \%$ \\
\hline $\mathrm{LTV} \geq 95 \%$ & $2.63 \%$ & $19.34 \%$ & $39.81 \%$ & $0.47 \%$ & $2.39 \%$ & $3.86 \%$ & $3.10 \%$ & $21.73 \%$ & $43.67 \%$ \\
\hline \multicolumn{10}{|l|}{ By Buyers' Type } \\
\hline Repeat Buyer & $3.09 \%$ & $22.35 \%$ & $44.99 \%$ & $0.35 \%$ & $1.83 \%$ & $2.99 \%$ & $3.44 \%$ & $24.18 \%$ & $47.98 \%$ \\
\hline First Time Buyer & $2.57 \%$ & $18.93 \%$ & $39.15 \%$ & $0.44 \%$ & $2.22 \%$ & $3.52 \%$ & $3.01 \%$ & $21.15 \%$ & $42.67 \%$ \\
\hline \multicolumn{10}{|l|}{ By Housing Exp/Inc Ratio } \\
\hline $20 \%<\mathrm{HEI} \leq 38 \%$ & $2.97 \%$ & $21.57 \%$ & $43.73 \%$ & $0.41 \%$ & $2.04 \%$ & $3.24 \%$ & $3.37 \%$ & $23.60 \%$ & $46.97 \%$ \\
\hline Otherwise & $2.36 \%$ & $17.51 \%$ & $36.51 \%$ & $0.49 \%$ & $2.56 \%$ & $4.19 \%$ & $2.86 \%$ & $20.07 \%$ & $40.70 \%$ \\
\hline \multicolumn{10}{|l|}{ By Credit Score } \\
\hline Credit Score $\geq 680$ & $3.23 \%$ & $22.88 \%$ & $45.67 \%$ & $0.28 \%$ & $1.41 \%$ & $2.24 \%$ & $3.51 \%$ & $24.29 \%$ & $47.91 \%$ \\
\hline Credit Score $<620$ & $2.20 \%$ & $16.74 \%$ & $35.22 \%$ & $1.04 \%$ & $5.25 \%$ & $8.44 \%$ & $3.24 \%$ & $21.98 \%$ & $43.66 \%$ \\
\hline \multicolumn{10}{|l|}{ By Risk Type } \\
\hline Low Credit Risk & $3.99 \%$ & $27.55 \%$ & $53.12 \%$ & $0.21 \%$ & $1.03 \%$ & $1.60 \%$ & $4.20 \%$ & $28.59 \%$ & $54.72 \%$ \\
\hline High Credit Risk & $1.96 \%$ & $15.02 \%$ & $31.90 \%$ & $1.18 \%$ & $5.95 \%$ & $9.64 \%$ & $3.13 \%$ & $20.97 \%$ & $41.53 \%$ \\
\hline
\end{tabular}

Note: The calculation of probability for each risk group is based on 10\% random sample of the mortgage pools originated in June 1992 . For each group, probabilities are evaluated at the mean value of each covariate (time-varying means are calculated for time-varying covariates) except for those specified in each risk category such that

(1) Liquid asset is evaluated at $75 \%$ and $25 \%$ quartiles of the sample for higher and lower liquid asset groups, respectively.

(2) LTV is set to $95 \%$, and $80 \%$ for high LTV category, and low LTV category, respectively.

(3) Weighted average of borrowers with credit score between 680 and 740, and credit score above 740 is used to define high credit score group; and weighted average of borrowers with credit below 620 is used to define low credit score group.

(4) The low credit risk group consists of borrowers with liquid asset above sample median, LTV under 95\%, repeat-buyer, housing expense to income ratio between $20 \%$ and $38 \%$, and credit score above 680 .

(5) The high credit risk group consists of borrowers with liquid asset below sample median, LTV above 95\%, first-time buyer, housing expense to income ratio greater than $38 \%$, and credit score under 620 .

(6) The cumulative probabilities of total termination at the end of year 1, 3, and 5 are the sum of predicted cumulative prepayment and default rates at the end of year 1,3 , and 5 , respectively. 
APPENDIX A

TABLE A1-MAXIMUM LIKELIHOOD ESTIMATES FOR COMPETING RISKS OF FHA MORTGAGE PREPAYMENT AND DEFAULT WITH CENSUS TRACT CONTROLS

\begin{tabular}{|c|c|c|c|c|c|c|}
\hline & \multicolumn{2}{|c|}{ Model 1} & \multicolumn{2}{|c|}{ Model 2} & \multicolumn{2}{|c|}{ Model 3} \\
\hline & Prepay & Default & Prepay & Default & Prepay & Default \\
\hline $\begin{array}{l}\text { Call Option (fraction of } \\
\text { Contract value) }\end{array}$ & & & $\begin{array}{c}4.911 \\
(27.13)\end{array}$ & $\begin{array}{l}2.423 \\
(3.85)\end{array}$ & & \\
\hline $\begin{array}{l}\text { Put Option (probability } \\
\text { of negative equity) }\end{array}$ & & & $\begin{array}{l}-1.691 \\
(12.52)\end{array}$ & $\begin{array}{l}1.807 \\
(6.66)\end{array}$ & & \\
\hline $\begin{array}{l}\text { Interaction of Call Option } \\
\text { Credit Scores }<620\end{array}$ & & & & & $\begin{array}{c}4.495 \\
(10.59)\end{array}$ & $\begin{array}{l}2.499 \\
(2.26)\end{array}$ \\
\hline $\begin{array}{l}\text { Interaction of Call Option } \\
\text { Credit Scores } 620 \sim 680\end{array}$ & & & & & $\begin{array}{c}4.142 \\
(13.11)\end{array}$ & $\begin{array}{l}1.737 \\
(1.78)\end{array}$ \\
\hline $\begin{array}{l}\text { Interaction of Call Option } \\
\text { Credit Scores } 680 \sim 740\end{array}$ & & & & & $\begin{array}{c}5.367 \\
(18.10)\end{array}$ & $\begin{array}{l}1.844 \\
(1.51)\end{array}$ \\
\hline $\begin{array}{l}\text { Interaction of Call Option } \\
\text { Credit Scores }>740\end{array}$ & & & & & $\begin{array}{l}5.868 \\
(15.99)\end{array}$ & $\begin{array}{l}2.734 \\
(1.45)\end{array}$ \\
\hline $\begin{array}{l}\text { Interaction of Put Option } \\
\text { Credit Scores }<620\end{array}$ & & & & & $\begin{array}{l}-2.749 \\
(6.75)\end{array}$ & $\begin{array}{l}2.299 \\
(4.83)\end{array}$ \\
\hline $\begin{array}{l}\text { Interaction of Put Option } \\
\text { Credit Scores } 620 \sim 680\end{array}$ & & & & & $\begin{array}{l}-2.440 \\
(9.03)\end{array}$ & $\begin{array}{l}1.705 \\
(4.35)\end{array}$ \\
\hline $\begin{array}{l}\text { Interaction of Put Option } \\
\text { Credit Scores } 680 \sim 740\end{array}$ & & & & & $\begin{array}{l}-1.681 \\
(8.17)\end{array}$ & $\begin{array}{l}2.032 \\
(4.61)\end{array}$ \\
\hline $\begin{array}{l}\text { Interaction of Put Option } \\
\text { Credit Scores }>740\end{array}$ & & & & & $\begin{array}{l}-0.944 \\
(4.51)\end{array}$ & $\begin{array}{l}2.225 \\
(3.00)\end{array}$ \\
\hline $\begin{array}{l}\text { SMSA Unemployment } \\
\text { Rate (percent) }\end{array}$ & $\begin{array}{l}-0.131 \\
(17.44)\end{array}$ & $\begin{array}{l}0.109 \\
(5.47)\end{array}$ & $\begin{array}{l}-0.107 \\
(13.50)\end{array}$ & $\begin{array}{l}0.054 \\
(2.38)\end{array}$ & $\begin{array}{l}-0.107 \\
(13.39)\end{array}$ & $\begin{array}{l}0.054 \\
(2.40)\end{array}$ \\
\hline $\begin{array}{l}\text { Log Value of Herfindahl } \\
\text { Hirschmann Index }\end{array}$ & $\begin{array}{l}0.032 \\
(1.13)\end{array}$ & $\begin{array}{l}-0.424 \\
(3.21)\end{array}$ & $\begin{array}{l}0.008 \\
(0.27)\end{array}$ & $\begin{array}{l}-0.388 \\
(2.92)\end{array}$ & $\begin{array}{l}-0.001 \\
(0.05)\end{array}$ & $\begin{array}{l}-0.375 \\
(2.80)\end{array}$ \\
\hline $\begin{array}{l}\text { Interaction of Black } \\
\text { and Log of H-H Index }\end{array}$ & $\begin{array}{l}0.190 \\
(1.76)\end{array}$ & $\begin{array}{l}-0.229 \\
(0.85)\end{array}$ & $\begin{array}{l}0.153 \\
(1.41)\end{array}$ & $\begin{array}{l}-0.263 \\
(0.98)\end{array}$ & $\begin{array}{l}0.148 \\
(1.36)\end{array}$ & $\begin{array}{l}-0.251 \\
(0.93)\end{array}$ \\
\hline $\begin{array}{l}\text { Interaction of Hispanic } \\
\text { and Log of H-H Index }\end{array}$ & $\begin{array}{l}0.127 \\
(1.16)\end{array}$ & $\begin{array}{l}-0.266 \\
(0.84)\end{array}$ & $\begin{array}{l}0.221 \\
(2.03)\end{array}$ & $\begin{array}{l}-0.126 \\
(0.39)\end{array}$ & $\begin{array}{l}0.239 \\
(2.18)\end{array}$ & $\begin{array}{l}-0.167 \\
(0.51)\end{array}$ \\
\hline $\begin{array}{l}\text { Credit Scores }<620 \\
\text { (dummy) }\end{array}$ & & & & & $\begin{array}{l}-0.004 \\
(0.06)\end{array}$ & $\begin{array}{l}1.696 \\
(5.29)\end{array}$ \\
\hline $\begin{array}{l}\text { Credit Scores 620 680 } \\
\text { (dummy) }\end{array}$ & & & & & $\begin{array}{l}0.056 \\
(1.07)\end{array}$ & $\begin{array}{l}1.377 \\
(4.52)\end{array}$ \\
\hline $\begin{array}{l}\text { Credit Scores 680 740 } \\
\text { (dummy) }\end{array}$ & & & & & $\begin{array}{l}0.012 \\
(0.25)\end{array}$ & $\begin{array}{l}0.745 \\
(2.33)\end{array}$ \\
\hline
\end{tabular}


TABLE A1-Continued.

\begin{tabular}{|c|c|c|c|c|c|c|}
\hline & \multicolumn{2}{|c|}{ Model 1} & \multicolumn{2}{|c|}{ Model 2} & \multicolumn{2}{|c|}{ Model 3} \\
\hline & Prepay & Default & Prepay & Default & Prepay & Default \\
\hline Black (dummy) & $\begin{array}{l}-1.514 \\
(2.49)\end{array}$ & $\begin{array}{l}1.977 \\
(1.31)\end{array}$ & $\begin{array}{l}-1.387 \\
(2.26)\end{array}$ & $\begin{array}{l}2.172 \\
(1.44)\end{array}$ & $\begin{array}{l}-1.330 \\
(2.16)\end{array}$ & $\begin{array}{l}1.848 \\
(1.22)\end{array}$ \\
\hline Asian (dummy) & $\begin{array}{l}-0.073 \\
(0.79)\end{array}$ & $\begin{array}{l}-0.057 \\
(0.13)\end{array}$ & $\begin{array}{l}-0.008 \\
(0.09)\end{array}$ & $\begin{array}{l}-0.153 \\
(0.36)\end{array}$ & $\begin{array}{l}-0.000 \\
(0.00)\end{array}$ & $\begin{array}{r}-0.162 \\
(0.35)\end{array}$ \\
\hline Hispanic (dummy) & $\begin{array}{l}-0.938 \\
(1.53)\end{array}$ & $\begin{array}{l}1.796 \\
(1.00)\end{array}$ & $\begin{array}{l}-1.538 \\
(2.50)\end{array}$ & $\begin{array}{l}0.956 \\
(0.52)\end{array}$ & $\begin{array}{l}-1.627 \\
(2.63)\end{array}$ & $\begin{array}{l}1.095 \\
(0.59)\end{array}$ \\
\hline Others (dummy) & $\begin{array}{l}-0.244 \\
(2.46)\end{array}$ & $\begin{array}{l}0.196 \\
(0.64)\end{array}$ & $\begin{array}{l}-0.356 \\
(3.57)\end{array}$ & $\begin{array}{l}0.077 \\
(0.26)\end{array}$ & $\begin{array}{l}-0.319 \\
(3.19)\end{array}$ & $\begin{array}{r}-0.116 \\
(0.38)\end{array}$ \\
\hline Loan-to-Value Ratio & $\begin{array}{l}-1.483 \\
(7.69)\end{array}$ & $\begin{array}{l}2.016 \\
(2.19)\end{array}$ & $\begin{array}{l}-1.329 \\
(7.08)\end{array}$ & $\begin{array}{l}2.529 \\
(2.71)\end{array}$ & $\begin{array}{l}-1.353 \\
(7.18)\end{array}$ & $\begin{array}{l}2.385 \\
(2.49)\end{array}$ \\
\hline $\begin{array}{l}\text { Housing Exp. to Income } \\
20 \sim 38 \% \text { (dummy) }\end{array}$ & $\begin{array}{l}0.236 \\
(5.92)\end{array}$ & $\begin{array}{l}0.178 \\
(1.11)\end{array}$ & $\begin{array}{l}0.220 \\
(5.26)\end{array}$ & $\begin{array}{l}-0.206 \\
(1.19)\end{array}$ & $\begin{array}{l}0.229 \\
(5.44)\end{array}$ & $\begin{array}{l}-0.196 \\
(1.10)\end{array}$ \\
\hline $\begin{array}{l}\text { Housing Exp. to Income } \\
>38 \% \text { (dummy) }\end{array}$ & $\begin{array}{l}0.329 \\
(2.29)\end{array}$ & $\begin{array}{l}0.019 \\
(0.03)\end{array}$ & $\begin{array}{l}0.050 \\
(0.34)\end{array}$ & $\begin{array}{l}-0.102 \\
(0.18)\end{array}$ & $\begin{array}{l}0.044 \\
(0.30)\end{array}$ & $\begin{array}{l}0.092 \\
(0.16)\end{array}$ \\
\hline $\begin{array}{l}\text { Debt to Income Ratio } \\
20 \sim 41 \% \text { (dummy) }\end{array}$ & $\begin{array}{l}0.113 \\
(1.47)\end{array}$ & $\begin{array}{l}-0.267 \\
(0.79)\end{array}$ & $\begin{array}{l}0.010 \\
(0.12)\end{array}$ & $\begin{array}{l}-0.272 \\
(0.81)\end{array}$ & $\begin{array}{l}0.014 \\
(0.18)\end{array}$ & $\begin{array}{l}-0.404 \\
(1.20)\end{array}$ \\
\hline $\begin{array}{l}\text { Debt to Income Ratio } \\
41 \sim 53 \% \text { (dummy) }\end{array}$ & $\begin{array}{l}0.223 \\
(2.69)\end{array}$ & $\begin{array}{l}-0.060 \\
(0.17)\end{array}$ & $\begin{array}{l}0.088 \\
(1.05)\end{array}$ & $\begin{array}{l}-0.074 \\
(0.21)\end{array}$ & $\begin{array}{l}0.107 \\
(1.26)\end{array}$ & $\begin{array}{l}-0.287 \\
(0.81)\end{array}$ \\
\hline $\begin{array}{l}\text { Debt to Income Ratio } \\
>53 \% \text { (dummy) }\end{array}$ & $\begin{array}{l}0.292 \\
(1.80)\end{array}$ & $\begin{array}{l}-0.519 \\
(0.73)\end{array}$ & $\begin{array}{l}0.044 \\
(0.28)\end{array}$ & $\begin{array}{l}-0.591 \\
(0.83)\end{array}$ & $\begin{array}{l}0.061 \\
(0.38)\end{array}$ & $\begin{array}{l}-0.852 \\
(1.20)\end{array}$ \\
\hline $\begin{array}{l}\text { Buydown } \\
\text { (dummy) }\end{array}$ & $\begin{array}{l}0.249 \\
(3.23)\end{array}$ & $\begin{array}{l}0.078 \\
(0.26)\end{array}$ & $\begin{array}{l}0.167 \\
(2.17)\end{array}$ & $\begin{array}{l}-0.067 \\
(0.22)\end{array}$ & $\begin{array}{l}0.162 \\
(2.11)\end{array}$ & $\begin{array}{r}-0.017 \\
(0.06)\end{array}$ \\
\hline $\begin{array}{l}\text { Log Value of Property } \\
\text { Appraisal Value }\end{array}$ & $\begin{array}{l}-0.104 \\
(1.74)\end{array}$ & $\begin{array}{l}0.165 \\
(0.77)\end{array}$ & $\begin{array}{l}0.213 \\
(3.42)\end{array}$ & $\begin{array}{l}0.325 \\
(1.46)\end{array}$ & $\begin{array}{l}0.208 \\
(3.34)\end{array}$ & $\begin{array}{l}0.347 \\
(1.52)\end{array}$ \\
\hline $\begin{array}{l}\text { Mortgage Term }<30 \text { Year } \\
\text { (dummy) }\end{array}$ & $\begin{array}{l}-0.299 \\
(4.37)\end{array}$ & $\begin{array}{r}-1.088 \\
(2.39)\end{array}$ & $\begin{array}{l}-0.035 \\
(0.50)\end{array}$ & $\begin{array}{l}-0.858 \\
(1.87)\end{array}$ & $\begin{array}{l}-0.042 \\
(0.60)\end{array}$ & $\begin{array}{l}-0.814 \\
(1.74)\end{array}$ \\
\hline $\begin{array}{l}\text { Central City Location } \\
\text { (dummy) }\end{array}$ & $\begin{array}{l}0.032 \\
(1.14)\end{array}$ & $\begin{array}{l}-0.143 \\
(1.37)\end{array}$ & $\begin{array}{l}0.036 \\
(1.29)\end{array}$ & $\begin{array}{r}-0.144 \\
(1.38)\end{array}$ & $\begin{array}{l}0.038 \\
(1.35)\end{array}$ & $\begin{array}{r}-0.124 \\
(1.17)\end{array}$ \\
\hline $\begin{array}{l}\text { Rural } \\
\text { (dummy) }\end{array}$ & $\begin{array}{l}0.029 \\
(0.51)\end{array}$ & $\begin{array}{l}-0.207 \\
(0.91)\end{array}$ & $\begin{array}{l}0.030 \\
(0.53)\end{array}$ & $\begin{array}{l}-0.242 \\
(1.09)\end{array}$ & $\begin{array}{l}0.033 \\
(0.58)\end{array}$ & $\begin{array}{l}-0.182 \\
(0.80)\end{array}$ \\
\hline $\begin{array}{l}\text { First Time Home Buyer } \\
\text { (dummy) }\end{array}$ & $\begin{array}{l}-0.184 \\
(6.54)\end{array}$ & $\begin{array}{l}0.128 \\
(1.16)\end{array}$ & $\begin{array}{l}-0.194 \\
(6.86)\end{array}$ & $\begin{array}{l}0.122 \\
(1.11)\end{array}$ & $\begin{array}{l}-0.187 \\
(6.59)\end{array}$ & $\begin{array}{l}0.058 \\
(0.53)\end{array}$ \\
\hline $\begin{array}{l}\text { New House } \\
\text { (dummy) }\end{array}$ & $\begin{array}{l}-0.134 \\
(2.80)\end{array}$ & $\begin{array}{l}-0.103 \\
(0.54)\end{array}$ & $\begin{array}{l}-0.036 \\
(0.74)\end{array}$ & $\begin{array}{l}-0.069 \\
(0.36)\end{array}$ & $\begin{array}{l}-0.039 \\
(0.81)\end{array}$ & $\begin{array}{r}-0.044 \\
(0.23)\end{array}$ \\
\hline
\end{tabular}


TABLE A1-Continued.

\begin{tabular}{|c|c|c|c|c|c|c|}
\hline & \multicolumn{2}{|c|}{ Model 1} & \multicolumn{2}{|c|}{ Model 2} & \multicolumn{2}{|c|}{ Model 3} \\
\hline & Prepay & Default & Prepay & Default & Prepay & Default \\
\hline $\begin{array}{l}\text { Unmarried Co-borrower } \\
\text { (dummy) }\end{array}$ & $\begin{array}{l}-0.006 \\
(0.14)\end{array}$ & $\begin{array}{l}-0.106 \\
(0.59)\end{array}$ & $\begin{array}{l}-0.008 \\
(0.18)\end{array}$ & $\begin{array}{l}-0.115 \\
(0.63)\end{array}$ & $\begin{array}{l}-0.012 \\
(0.28)\end{array}$ & $\begin{array}{l}-0.074 \\
(0.41)\end{array}$ \\
\hline $\begin{array}{l}\text { Single Male } \\
\text { (dummy) }\end{array}$ & $\begin{array}{l}0.017 \\
(0.47)\end{array}$ & $\begin{array}{l}0.313 \\
(2.45)\end{array}$ & $\begin{array}{l}-0.007 \\
(0.18)\end{array}$ & $\begin{array}{l}0.339 \\
(2.65)\end{array}$ & $\begin{array}{l}-0.004 \\
(0.11)\end{array}$ & $\begin{array}{l}0.307 \\
(2.38)\end{array}$ \\
\hline $\begin{array}{l}\text { Single Female } \\
\text { (dummy) }\end{array}$ & $\begin{array}{l}-0.089 \\
(2.24)\end{array}$ & $\begin{array}{l}-0.185 \\
(1.25)\end{array}$ & $\begin{array}{l}-0.105 \\
(2.65)\end{array}$ & $\begin{array}{l}-0.154 \\
(1.04)\end{array}$ & $\begin{array}{l}-0.105 \\
(2.63)\end{array}$ & $\begin{array}{l}-0.175 \\
(1.16)\end{array}$ \\
\hline Number of Dependents & $\begin{array}{l}-0.071 \\
(5.34)\end{array}$ & $\begin{array}{l}0.133 \\
(3.21)\end{array}$ & $\begin{array}{l}-0.083 \\
(6.27)\end{array}$ & $\begin{array}{l}0.124 \\
(3.01)\end{array}$ & $\begin{array}{l}-0.076 \\
(5.69)\end{array}$ & $\begin{array}{l}0.078 \\
(1.81)\end{array}$ \\
\hline $\begin{array}{l}\text { Log Value of Liquid } \\
\text { Assets }\end{array}$ & $\begin{array}{l}0.006 \\
(0.66)\end{array}$ & $\begin{array}{l}-0.092 \\
(3.01)\end{array}$ & $\begin{array}{l}0.016 \\
(1.91)\end{array}$ & $\begin{array}{l}-0.094 \\
(3.08)\end{array}$ & $\begin{array}{l}0.013 \\
(1.51)\end{array}$ & $\begin{array}{l}-0.067 \\
(2.09)\end{array}$ \\
\hline $\begin{array}{l}\text { Borrower Age }<25 \\
\text { (dummy) }\end{array}$ & $\begin{array}{l}0.417 \\
(7.48)\end{array}$ & $\begin{array}{l}0.247 \\
(1.33)\end{array}$ & $\begin{array}{l}0.443 \\
(7.90)\end{array}$ & $\begin{array}{l}0.313 \\
(1.68)\end{array}$ & $\begin{array}{l}0.446 \\
(7.94)\end{array}$ & $\begin{array}{l}0.212 \\
(1.12)\end{array}$ \\
\hline $\begin{array}{l}\text { Borrower Age } 25 \sim 35 \\
\text { (dummy) }\end{array}$ & $\begin{array}{l}0.244 \\
(5.67)\end{array}$ & $\begin{array}{l}-0.185 \\
(1.23)\end{array}$ & $\begin{array}{l}0.279 \\
(6.38)\end{array}$ & $\begin{array}{l}-0.129 \\
(0.85)\end{array}$ & $\begin{array}{l}0.278 \\
(6.36)\end{array}$ & $\begin{array}{l}-0.185 \\
(1.20)\end{array}$ \\
\hline $\begin{array}{l}\text { Borrower Age 35 45 } \\
\text { (dummy) }\end{array}$ & $\begin{array}{l}0.058 \\
(1.24)\end{array}$ & $\begin{array}{l}-0.174 \\
(1.06)\end{array}$ & $\begin{array}{l}0.065 \\
(1.37)\end{array}$ & $\begin{array}{l}-0.110 \\
(0.67)\end{array}$ & $\begin{array}{l}0.063 \\
(1.34)\end{array}$ & $\begin{array}{l}-0.156 \\
(0.94)\end{array}$ \\
\hline $\begin{array}{l}\text { Log Value of Household } \\
\text { Income }\end{array}$ & $\begin{array}{l}0.597 \\
(9.13)\end{array}$ & $\begin{array}{l}-0.344 \\
(1.39)\end{array}$ & $\begin{array}{l}0.222 \\
(3.26)\end{array}$ & $\begin{array}{l}-0.630 \\
(2.42)\end{array}$ & $\begin{array}{l}0.238 \\
(3.48)\end{array}$ & $\begin{array}{l}-0.747 \\
(2.81)\end{array}$ \\
\hline $\begin{array}{l}\text { Percentage of Black in } \\
\text { Census Tract Population }\end{array}$ & $\begin{array}{l}0.049 \\
(0.67)\end{array}$ & $\begin{array}{l}-0.010 \\
(0.03)\end{array}$ & $\begin{array}{l}0.029 \\
(0.39)\end{array}$ & $\begin{array}{l}-0.006 \\
(0.02)\end{array}$ & $\begin{array}{l}0.021 \\
(0.28)\end{array}$ & $\begin{array}{l}0.011 \\
(0.04)\end{array}$ \\
\hline $\begin{array}{l}\text { Percentage of Asian in } \\
\text { Census Tract Population }\end{array}$ & $\begin{array}{l}-0.385 \\
(1.14)\end{array}$ & $\begin{array}{l}1.142 \\
(1.17)\end{array}$ & $\begin{array}{l}-0.443 \\
(1.26)\end{array}$ & $\begin{array}{l}1.232 \\
(1.23)\end{array}$ & $\begin{array}{l}-0.397 \\
(1.12)\end{array}$ & $\begin{array}{l}1.156 \\
(1.10)\end{array}$ \\
\hline $\begin{array}{l}\text { Percentage of Hispanic in } \\
\text { Census Tract Population }\end{array}$ & $\begin{array}{l}0.070 \\
(0.74)\end{array}$ & $\begin{array}{l}0.054 \\
(0.15)\end{array}$ & $\begin{array}{l}0.086 \\
(0.92)\end{array}$ & $\begin{array}{l}0.035 \\
(0.09)\end{array}$ & $\begin{array}{l}0.089 \\
(0.94)\end{array}$ & $\begin{array}{l}0.039 \\
(0.10)\end{array}$ \\
\hline $\begin{array}{l}\text { Percentage of Others in } \\
\text { Census Tract Population }\end{array}$ & $\begin{array}{l}1.085 \\
(1.12)\end{array}$ & $\begin{array}{l}-5.501 \\
(0.79)\end{array}$ & $\begin{array}{l}1.190 \\
(1.15)\end{array}$ & $\begin{array}{l}-5.588 \\
(0.82)\end{array}$ & $\begin{array}{l}1.153 \\
(1.15)\end{array}$ & $\begin{array}{l}-6.116 \\
(0.87)\end{array}$ \\
\hline $\begin{array}{l}\text { Census Tract to MSA } \\
\text { Median Income Ratio }\end{array}$ & $\begin{array}{l}-0.063 \\
(1.08)\end{array}$ & $\begin{array}{l}-0.101 \\
(0.44)\end{array}$ & $\begin{array}{l}-0.084 \\
(1.42)\end{array}$ & $\begin{array}{l}-0.106 \\
(0.46)\end{array}$ & $\begin{array}{l}-0.082 \\
(1.38)\end{array}$ & $\begin{array}{l}-0.160 \\
(0.68)\end{array}$ \\
\hline Census Tract Rental Ratio & $\begin{array}{l}-0.064 \\
(0.71)\end{array}$ & $\begin{array}{l}-0.020 \\
(0.06)\end{array}$ & $\begin{array}{l}-0.068 \\
(0.74)\end{array}$ & $\begin{array}{l}-0.044 \\
(0.13)\end{array}$ & $\begin{array}{l}-0.064 \\
(0.69)\end{array}$ & $\begin{array}{l}-0.117 \\
(0.35)\end{array}$ \\
\hline Log Likelihood & \multicolumn{2}{|c|}{$-35,697$} & \multicolumn{2}{|c|}{$-35,242$} & \multicolumn{2}{|c|}{$-35,145$} \\
\hline
\end{tabular}

Note: T-ratios are in parentheses. All models are estimated by ML approach. Prepayment and default functions are considered as correlated competing risks and they are estimated jointly. Flexible baseline functions (following Han and Hausman, 1990) for prepayment and default are estimated simultaneously with the competing risks hazard functions. 